\title{
Moderate alcohol consumption and increased bone mineral density: potential ethanol and non-ethanol mechanisms
}

\author{
R. Jugdaohsingh ${ }^{1}$, M. A. O'Connell ${ }^{2}$, S. Sripanyakorn ${ }^{1}$ and J. J. Powell ${ }^{* 2}$ \\ ${ }^{1}$ Gastrointestinal Laboratory, The Rayne Institute, St Thomas' Hospital, London SE1 7EH, UK \\ ${ }^{2}$ MRC Human Nutrition Research, Elsie Widdowson Laboratory, Fulbourn Road, Cambridge CB1 9NL, UK
}

\begin{abstract}
Mounting epidemiological evidence indicates an association between the moderate ingestion of alcoholic beverages and higher bone mineral density ( $v$. abstainers). More limited findings provide some evidence for translation of this association into reduced fracture risk, but further studies are required. Here, these data are reviewed and caveats in their assimilation, comparison and interpretation as well as in the use and application of bone health indices are discussed. Whilst it is concluded that evidence is now strong for the moderate alcohol-bone health association, at least in relation to bone mineral density, mechanisms are less clear. Both ethanol and non-ethanol components have been implicated as factors that positively affect bone health in the light of moderate consumption of alcoholic beverages, and four particular areas are discussed. First, recent findings suggest that moderate ethanol consumption acutely inhibits bone resorption, in a non-parathyroid hormone- and non-calcitonin-dependent fashion, which can only partly be attributed to an energy effect. Second, critical review of the literature does not support a role for moderate ethanol consumption affecting oestrogen status and leading to a knock-on effect on bone. Third, Si is present at high levels in certain alcoholic beverages, especially beer, and may have a measurable role in promoting bone formation. Fourth, a large body of work indicates that phytochemicals (e.g. polyphenols) from alcoholic beverages could influence bone health, but human data are lacking. With further work it is hoped to be able to model epidemiological observations and provide a clear pathway between the magnitude of association and the relative contribution of these mechanisms for the major classes of alcoholic beverage.
\end{abstract}

Bone health: Moderate alcohol intake: Mechanisms: Silicon: Phytochemicals

It has long been known that excessive alcohol consumption has a negative impact on bone health and that chronic abusive consumption, as with many organs, has catastrophic effects. However, relatively recent epidemiological evidence has suggested that the moderate consumption of alcoholic beverages may have beneficial effects on bone, especially in post-menopausal women. The present review attempts to summarise the current evidence and discusses potential mechanisms (both ethanol-related and non-ethanol-related), but begins by considering the caveats in assimilation of such data.

First, for multiple reasons, the definition of moderate alcohol consumption is not at all clear. Indeed, there are differing guidelines on acceptable intakes of alcoholic beverages between nations (Table 1; International Center for Alcohol Policies, 2003). For example, in the USA guidelines for daily intake indicate 'up to one standard drink for women and up to two for men' while in the UK it is 'up to two to three units for women and up to four for men'. In certain countries it is $\geq 40 \mathrm{~g}$ alcohol/d (i.e. up to a half bottle of wine or five UK units). These variable guidelines illustrate the second problem, i.e. the consumer's ability to identify parity between $g$ alcohol, standard drinks, units etc. The term 'unit', as used in the UK, is especially old-fashioned. It is equivalent to $8 \mathrm{~g}$ alcohol (i.e. ethanol), which, for example, equates to $125 \mathrm{ml}$ wine with $9 \%(\mathrm{v} / \mathrm{v})$ ethanol. Few such wines are now drunk in most of the world (with Germany a notable exception), and one

\footnotetext{
Abbreviations: BMD, bone mineral density; C-terminal, carboxy-terminal; CTx, C-terminal cross-linked telopeptide of type I collagen; DXA, dual-energy X-ray absorptiometry; EGCG, epigallocatechin gallate; ER, oestrogen receptors; HRT, hormone-replacement therapy; N-terminal, amino-terminal; OR, odds ratio; PN, prenylnaringenin; PTH, parathyroid hormone; RANK, receptor activator of NF- $\kappa \mathrm{B}$; XH, xanthohumol.

*Corresponding author: Professor Jonathan J. Powell, fax + 441223 437515, email Jonathan.Powell@mrc-hnr.cam.ac.uk
} 
Table 1. International guidelines on acceptable intakes of alcoholic beverages (from International Center for Alcohol Policies, 2003)

\begin{tabular}{|c|c|c|c|c|}
\hline \multirow[b]{2}{*}{ Country } & \multirow{2}{*}{$\begin{array}{l}\text { Standard } \\
\text { drink (g ethanol) }\end{array}$} & \multicolumn{2}{|c|}{$\begin{array}{l}\text { Daily consumption } \\
\text { guidelines }(\mathrm{g})\end{array}$} & \multirow[b]{2}{*}{ Source } \\
\hline & & Men & Women & \\
\hline Australia & 10 & $\leq 40$ & $\leq 20$ & National Health Medical Research Council \\
\hline Austria & 10 & 24 & 16 & Federal Ministry for Labour, Health and Social Affairs \\
\hline Canada & $13 \cdot 6$ & $\leq 27 \cdot 2$ & $\leq 27 \cdot 2$ & $\begin{array}{l}\text { Centre for Addiction and Mental Health, } \\
\text { Addictions Research Foundation }\end{array}$ \\
\hline Czech Republic & & 24 & 16 & National Institute of Public Health \\
\hline Denmark & 12 & 36 & 24 & National Board of Health \\
\hline Finland & 11 & $\leq 23 \cdot 6$ & $\leq 15 \cdot 7$ & Oy Alko AB \\
\hline \multirow[t]{2}{*}{ France } & $8-12^{*}$ & $\leq 20$ & $\leq 20$ & Ministry of Health, Family and Persons with Disablility \\
\hline & 12 & $\leq 60$ & $\leq 36$ & National Academy of Medicine \\
\hline Republic of Ireland & 8 & 24 & $12 \cdot 7$ & Department of Health \\
\hline Italy & 12 & $\leq 24-36$ & $\leq 12-24$ & $\begin{array}{l}\text { Ministry for Agriculture and Forestry, } \\
\text { National Institute for Food and Nutrition }\end{array}$ \\
\hline Japan & $19 \cdot 75$ & \multicolumn{2}{|c|}{$19 \cdot 75-39 \cdot 5$} & Ministry of Health, Labour and Welfare \\
\hline The Netherlands & $9 \cdot 9$ & $\leq 39$ & $\leq 39$ & Stichting Verantwoord Alcoholgebruik \\
\hline New Zealand & 10 & $\leq 30$ & $\leq 20$ & Alcohol Liquor Advisory Council \\
\hline \multicolumn{2}{|l|}{ Romania } & \multicolumn{2}{|c|}{$\begin{array}{l}\leq 32.5 \mathrm{~g} \text { for beer } \\
\text { and } \leq 20.7 \mathrm{~g} \text { for wine }\end{array}$} & Ministry of Health \\
\hline South Africa & 12 & $\leq 36$ & $\leq 24$ & $\begin{array}{l}\text { South African National Council on } \\
\text { Alcoholism and Drug Dependence }\end{array}$ \\
\hline \multirow[t]{3}{*}{ Spain } & 10 & $\leq 30$ & $\leq 30$ & $\begin{array}{l}\text { Ministry of Health, Spanish Institute for } \\
\text { the Investigation of Beverage Alcohol }\end{array}$ \\
\hline & & $\leq 70$ & $\leq 70$ & $\begin{array}{l}\text { Basque Country: Department of Health and } \\
\text { Social Security }\end{array}$ \\
\hline & $8-10$ & $\leq 32-50$ & $\leq 32-50$ & Catalonia: Central Authority \\
\hline Sweden & & $\leq 20$ & $\leq 20$ & Swedish Research Council \\
\hline Switzerland & $10-12$ & $\leq 24$ & $\leq 24$ & $\begin{array}{l}\text { Swiss Federal Commission for Alcohol Problems, } \\
\text { Swiss Institute for the Prevention of Alcohol and } \\
\text { Drugs Problems }\end{array}$ \\
\hline UK & 8 & $\leq 24-32$ & $\leq 16-24$ & Department of Health \\
\hline USA & 14 & $\leq 28$ & $\leq 14$ & $\begin{array}{l}\text { Department of Agriculture, Department of } \\
\text { Health and Human Services }\end{array}$ \\
\hline
\end{tabular}

${ }^{*}$ For wine $8 \mathrm{~g}$, for beer $12 \mathrm{~g}$.

glass of wine in the UK is often $150-250 \mathrm{ml}$. Thus, today, a single glass of wine at $250 \mathrm{ml}$ and $13 \%(\mathrm{v} / \mathrm{v})$ alcohol contains more than three units alcohol. This disparity, in turn, leads on to the third problem, i.e. that the methodology for assessing alcohol intake is still evolving (Dawson, 2003). The metabolism and action of ethanol depends on how rapidly it is consumed and whether it is in the presence or absence of food, amongst other likely variables, and there are limited tools for the measurements of these interactions in free-living subjects. Moreover, as noted earlier, serving size and alcohol levels of wine, some beers and especially mixed drinks with spirits (liquor) can vary greatly, potentially leading to poor recognition by social drinkers of how much ethanol may be contained in a drink. Additionally, for obvious reasons, recall and diarybased methodologies may be limited in assessing alcohol consumption. Although this problem should manifest mostly with binge drinking and chronic abusive consumption rather than with moderate consumption, data collection still requires carefully-considered methodology and should be fit-for-purpose in relation to any associated outcome measure, such as health effects (Dawson, 2003). Unfortunately, many studies have simply relied on assessment of alcohol intake as a poorly-validated 'bolt-on' to more established dietary assessment methods. A fourth problem in defining moderate consumption is that ethanolrelated health effects (both positive and negative) vary between populations (men $v$. women, premenopausal $v$. post-menopausal women etc.); indeed, inter-population variation is commonly observed for the health effects of nutrients per se but is especially pronounced for ethanol. Genetic background greatly influences the metabolism of alcohol, while different tissues have differing sensitivities to ethanol; thus, female cancers have been associated with low levels of alcohol intake whereas cardiovascular protection in older men has been observed even with relatively-high levels of alcohol intake (da Luz \& Coimbra, 2004). In the following review, almost all the work refers to alcohol intakes of $\leq 40 \mathrm{~g}$ per capita per $\mathrm{d}$ (or, in one study, for the purpose of mechanistic discussion, $<0.7 \mathrm{~g} / \mathrm{kg}$ ).

Second, the evidence for an association between moderate alcohol intake and positive effects on bone health has mainly been observed in post-menopausal women. This situation probably reflects the fact that population-based studies of bone health predominate in this group rather than an indication of some special alcohol-bone mineral density (BMD) interaction. Nonetheless, caution should 
be exercised when extrapolating findings to men or premenopausal women for many of the reasons outlined earlier and in some of the following text.

Third, much of the methodology that has been used in published studies can be criticised. Numbers are often low, methodology for data collection (see earlier discussion) and/or analysis (see following discussion) is often poor and, in some studies, alcohol has been investigated as part of a great number of nutrients, meaning that $a$ priori hypotheses have not been tested. Methodology is generally incomparable between studies and a common problem has been the use of simple linear regression models to test observations between alcohol intake and BMD. This latter point is important because most studies investigating alcohol intake and health have recognised that a ' $\mathrm{J}$ '-shaped curve tends to be seen such that moderate ingestion offers maximum protection, but increased intake beyond this level shows increased risks (de Lorimier, 2000; da Luz $\&$ Coimbra, 2004). For this reason categorical data can be more useful when looking at the detailed association between alcohol intake and health (including bone health), while linear models are really only useful for an initial global overview, especially when studying potential covariate interactions (Jugdaohsingh et al. 2004). Finally, patterns of alcohol intake are likely to associate strongly with other lifestyle factors, and although many of these factors can be incorporated into epidemiological models, it is unlikely that they can all be incorporated, which adds to the 'statistical noise'.

In spite of these caveats some relatively-consistent findings have emerged in recent years, which will be summarised together with some speculation on mechanisms, but first an overview of the indicators of bone health will be provided.

\section{Bone mineral content and density}

Bone mineral content, the amount of mineral in a defined section of bone, can be measured to high precision $(\geq 94 \%)$ by a number of techniques; chiefly, X-ray absorptiometry, single-energy X-ray absorptiometry, dualenergy X-ray absorptiometry (DXA), quantitative computed tomography, peripheral quantitative computed tomography and quantitative ultrasound (Kleerekoper \& Nelson, 1997; Elliott \& Binkley, 2004; Cummings et al. 2005). The most-commonly-used method is DXA, which gives a measure of bone mineral content over a projected two-dimensional area $\left(\mathrm{g} / \mathrm{cm}^{2}\right)$, traditionally referred to as $\mathrm{BMD}$, although strictly speaking this measure is an 'area density' (Manolagas et al. 2002). BMD, measured by DXA, is the standard tool used in the diagnosis of osteoporosis and other diseases of bone fragility, since epidemiological studies have shown a strong relationship between the decline in BMD and the increased risk of fracture (Kleerekoper \& Nelson, 1997; Diez, 2002; Elliott \& Binkley, 2004; Wehren \& Siris, 2004; Cummings et al. 2005; Felsenberg \& Boonen, 2005). Indeed, BMD correlates strongly with bone strength, accounting for approximately $60-85 \%$ of its strength (Wehren \& Siris, 2004; Felsenberg \& Boonen, 2005). Thus, BMD is used as a good indicator or predictor of future fracture risk within but not between populations (Melton et al. 2003). The World Health Organization (2003) criteria define osteoporosis, based on hip BMD measurements, as a BMD score (or 'T-score') $\geq 2.5$ sD below the mean of a young (25-45 years old) adult of the same sex (i.e. $T$ score $\leq-2 \cdot 5)$ and osteopenia as $\mathrm{T}$-score $<-1$ but $>-2 \cdot 5$. For each $1 \mathrm{SD}$ decline in BMD there is a 2 -fold increase in fracture risk compared with an individual with a normal BMD (Wehren \& Siris, 2004; Cummings et al. 2005; Johnell et al. 2005; Miller et al. 2005). Z-scores, used less routinely and not for diagnosis, are relative to individuals of the same age and gender (i.e. are age-matched scores; Elliott \& Binkley, 2004; Cummings et al. 2005).

Recently, however, there has been much debate about the exclusive use or over-reliance on BMD measurements in predicting fracture risk, since it fails to predict fractures in certain cases. For example, the small increase in BMD (1-5\% over several years) seen with anti-resorptive therapy (e.g. bisphophonates) cannot account for the large reduction in fracture risk (approximately 20-70\%), or the continued reduction in fracture risk following treatment withdrawal when BMD has stabilised (Borah et al. 2003; Eastell et al. 2003; Khosla, 2003; Sato et al. 2003; Roux et al. 2005; Srivastava et al. 2005; P Delmas, unpublished results; E Seeman, unpublished results); in these cases only $5-28 \%$ of the reduction in fracture risk is accounted for by the increase in BMD (Sarkar et al. 2004). Similarly, BMD measurement alone would miss the $10-17 \%$ women of $>50$ years of age who develop fractures, but have normal BMD (Garnero \& Delmas, 2004; Felsenberg \& Boonen, 2005). Further, it should be noted that BMD is an areal measurement that is only partially adjusted for bone and body size, and therefore artifactual associations may be observed because of confounding residual size (Prentice et al. 1994). These and other findings suggest that BMD measurement alone is not sufficient to predict fracture risk accurately in individuals (Cefalu, 2004) but, at the population level, and relevant to this discussion, it remains an extremely important proxy for long-term bone health.

Bone fracture occurs when the stress put on the tissue exceeds the strength of the material. However, bone is a complex composite substance and its strength is described by a number of structural and material properties that determine its quality (Felsenberg \& Boonen, 2005). Its structural properties are described by its geometry (i.e. size and shape) and micro-architecture (trabecular interconnection, spacing and thickness, and cortical thickness and porosity; Paschalis et al. 2004; Felsenberg \& Boonen, 2005). The material properties are described by the mineral and collagen compositions (extent of mineralisation, crystal size, collagen type and cross-links), the number, size and location of micro-damage and the rate of bone turnover (Felsenberg \& Boonen, 2005). DXA measures the extent of mineralisation, which is only one of the components that describe bone quality and strength (Marx, 2004; Felsenberg \& Boonen, 2005; Srivastava et al. 2005).

More recent techniques such as quantitative computed tomography, peripheral quantitative computed tomography and three-dimensional magnetic resonance micro-imaging provide more detailed information on the structural 
properties and thus bone quality (Malavolta et al. 2004; Felsenberg \& Boonen, 2005). They can also distinguish between cortical (less metabolically active) and trabecular (more metabolically active) bone, provide information on micro-architecture and give a true volumetric BMD measurement (i.e. $\mathrm{g} / \mathrm{cm}^{3}$ ). However, such methods are not yet as widely available as DXA in most clinical settings and, apart from quantitative ultrasound, there is an increase in the radiation exposure dose $(50-60 \mu \mathrm{Sv}$ with quantitative computed tomography compared with $0 \cdot 1-1 \mu \mathrm{Sv}$ with DXA; Elliott \& Binkley, 2004). Thus, currently, DXA remains the 'gold standard' for diagnosis and treatment monitoring of diseases of bone fragility, but its limitations must be borne in mind (Bessho, 2003; Fukunaga, 2003; Khosla, 2003; E Seeman, unpublished results). Factors that can increase the risk of fracture independently of BMD also need to be considered (age, body weight, height, BMI, free oestradiol index (or sex hormone-binding protein levels), grip strength, lifestyle factors (history of falling, smoking, alcohol consumption, physical activity, dietary intake), medical history of fracture, family history of osteoporosis and use of medication (e.g. steroids, anticonvulsive drugs, sedatives)), since these factors will enhance the predictive power of fracture risk (Albrand et al. 2003; Melton et al. 2003; Felsenberg \& Boonen, 2005; Johnell et al. 2005; Miller et al. 2005; Robbins et al. 2005). In addition, such factors should also be considered in epidemiological models investigating associations with fracture risk.

\section{Biochemical markers of bone turnover}

Bone is a living tissue that constantly undergoes renewal and repair (or remodelling). The cells responsible for this process are the bone-forming osteoblasts and the boneresorbing osteoclasts. In the adult skeleton the activities of these cells are normally coupled such that no marked net increase or loss of bone mass occurs (an average small loss of $0.4 \%$ year occurs; Srivastava et al. 2005). This coupling of activities also preserves the bone architecture (Teti, 2005). However, with bone diseases such as osteoporosis (e.g. as a result of oestrogen deficiency), bone turnoverremodelling is markedly increased and the activities of these cells are no longer coupled. Osteoclast activity dominates, as a result of an increase in osteoclast numbers over osteoblasts (Manolagas et al. 2002), and a marked net increase in bone loss occurs ( $>1-2 \%$ /year; Srivastava et al. 2005). Osteoblast activity is also raised as it tries, but fails, to counteract or compete with the increased bone loss. Bone formed by these cells may thus be less mineralised and prone to fracture. This high rate of bone turnover is correlated with bone loss in osteoporosis and can explain $50 \%$ of the variance in bone mass (Ebeling \& Akesson, 2001). Osteoporosis medications, such as bisphosphonates, work by reducing osteoclast activity and bone loss, thereby decreasing the rate of bone turnover. Measurement of the rate of bone turnover is therefore important and the most practical method for monitoring the efficacy of osteoporosis therapy and the management of individuals with bone fragility (Srivastava et al. 2005).
Importantly, the activities of the bone remodelling cells can be measured, since they release biochemical markers in blood and urine. Higher levels of these bone markers correlate with a higher rate of bone remodelling (Srivastava et al. 2005) and their assessment can be useful in supporting bone mineral status measurements of bone health.

\section{Bone formation markers}

Osteoblasts produce type I collagen as a pro-molecule (procollagen), which, on the formation of collagen matrix, releases the carboxy-terminal (C-terminal) and aminoterminal (N-terminal) extension peptides (Ebeling \& Akesson, 2001). These extension peptides (procollagen type I C-terminal peptide or procollagen type I N-terminal peptide) are released into the blood and can be measured by commercially-available immunoassays, and their levels are directly proportional to type I collagen synthesis and, theoretically therefore, bone formation. Type I collagen is also produced by fibroblasts in other connective tissues (e.g. skin), but the majority of the extension peptide detected in blood is derived from bone because of the higher rates and mass of bone turnover compared with other connective tissues. Measurement of procollagen type I $\mathrm{N}$-terminal peptide is generally preferred over procollagen type I C-terminal peptide because of the lack of sensitivity of the latter in detecting subtle changes in bone turnover (Ebeling \& Akesson, 2001). However, some of the procollagen type I N-terminal peptide released may become incorporated into bone and then later released during bone breakdown, and so a proportion of the amount measured may represent bone resorption (Ebeling \& Akesson, 2001).

Following collagen synthesis, osteoblasts undergo cellular differentiation into mature osteoblast cells that express high alkaline phosphatase activity and secrete osteocalcin during osteoid formation and mineralisation, both of which, again, can be measured by commerciallyavailable immunoassays. Bone-specific alkaline phosphatase is reported to show the highest specificity to bone, compared with the other formation markers, even though marked cross-reactivity $(\leq 10 \%)$ with liver isoenzymes may occur (Ebeling \& Akesson, 2001). Osteocalcin readily undergoes degradation and so the intact molecule and its fragments are present in blood, of which the N-MID fragment (so termed because it contains both the $\mathrm{N}$-terminal and the middle portion of the protein) is the largest (fortythree or forty-four amino acids). Assays that measure both the intact and N-MID fragment have been suggested to be more robust and sensitive than those that measure the intact molecule alone (Ebeling \& Akesson, 2001). Additionally, osteocalcin exists as mature (carboxylated) and immature (undercarboxylated) forms. The ratio of these two forms, or the extent of carboxylation, may influence mineralisation and has been used in the assessment of fracture risk (see later (p. 297); Ebeling \& Akesson, 2001).

These three markers, i.e. the procollagen type I $\mathrm{C}$-terminal and $\mathrm{N}$-terminal peptides, bone-specific alkaline phosphatase and osteocalcin, are known as early, mid and late biochemical markers of bone formation respectively, and are used as surrogate markers to determine the rate of bone formation. 


\section{Bone resorption markers}

Osteoclasts secrete enzymes that break down bone, leading to release into blood and urine of $\mathrm{Ca}$, phosphate and degradation fragments of the type I collagen matrix such as pyridinoline, deoxypyridinoline, C-terminal telopeptides (cross-linked telopeptide of type I collagen (CTx) and cross-linked C-terminal telopeptide of type I collagen), $\mathrm{N}$ terminal telopeptide and helical peptides (fragments of the helical region of the type I collagen $\alpha$ chain; Ebeling \& Akesson, 2001). These fragments vary in size (helical peptide $>$ cross-linked C-terminal telopeptide of type I collagen $>$ CTx approximately the same as N-terminal telopeptide $>$ pyridinoline approximately the same as deoxypyridinoline), type of cross-link (pyridinoline $v$. deoxypyridinoline) and the presence (cross-linked Cterminal telopeptide of type I collagen and helical peptides) and absence of the helical peptide chain. Crosslinked C-terminal telopeptide of type I collagen and CTx are suggested to respond to different clinical situations and treatments (Garnero et al. 2003a). The former may be more important in pathological situations such as metastatic bone diseases and multiple myeloma (Garnero et al. $2003 a$ ). Osteoclasts release acid phosphatases, and tartrateresistant acid phosphatase $5 \mathrm{~b}$ is a specific and direct marker of osteoclast activity (being released by active or activated osteoclasts) and its levels correlate with those of other bone-turnover markers and BMD (Gerdhem et al. 2004). Intact parathyroid hormone (PTH) levels have also been used as an indirect marker of bone resorption. However, the preferred markers of resorption are CTx and $\mathrm{N}$-terminal telopeptide in serum or plasma and pyridinoline and deoxypyridinoline in urine. N-terminal telopeptide is preferred over CTx, since it is more specific to bone (Ebeling \& Akesson, 2001). CTx may be derived from other connective tissues, although it has proved to be a useful marker of changes to bone resorption in wellcontrolled acute-dosing studies (e.g. following ingestion of Ca; Kamel et al. 1998; Guillemant et al. 2000, 2003). Tritiated tetracycline has been used in animal studies to measure the rate of bone resorption (Muhlbauer \& Fleisch, 1990; Muhlbauer et al. 2003) but the authors are not aware of its similar use in man.

When monitoring therapy, serum and urine levels of bone-turnover markers are measured in the fasting state, because of the influence of food intake, and at the same time of day, because of diurnal variation (usually in the morning when diurnal variation is lowest; Gerdhem et al. 2004; Roux et al. 2005). Bone-resorption markers in serum show greater diurnal variation than bone-formation markers in serum or either types of marker in urine (Ebeling \& Akesson, 2001; Gerdhem et al. 2004; Roux et al. 2005). Changes in levels (20-70\%) following the commencement of anti-resorptive treatment are usually seen within a few months (3 months for bone-resorption markers, but not before 6 months for bone-formation markers) compared with the minimum of 1-2 years to see a small change (1-2\%) in BMD (Sarkar et al. 2004; Cummings et al. 2005; Roux et al. 2005; Srivastava et al. 2005). Thus, bone markers allow the monitoring of treatment and are used as early indicators of treatment efficacy (e.g. to identify responders and non-responders). Bone markers are also used in the management of patients, since ongoing monitoring has recently been suggested to improve compliance with treatment (Ebeling \& Akesson, 2001; Srivastava et al. 2005).

Bone markers, however, show high inter- and intraindividual variation (5-30\% for serum and $10-50 \%$ for urinary markers) and are sensitive to factors that affect bone turnover such as sex hormone levels, diet, season, time of day and renal and hepatic functions (Woitge et al. 1998; Rapuri et al. 2002; Garnero et al. 2003b; Elliott \& Binkley, 2004; Felsenberg \& Boonen, 2005; Miller et al. 2005; Roux et al. 2005; Srivastava et al. 2005). Thus, their measurement cannot be used in the diagnosis of osteoporosis or other diseases of bone fragility, but only in monitoring the response to treatment or in populationbased studies. Nonetheless, Garnero et al. (2003b) have recently shown that CTx and osteocalcin levels can be used to classify subjects as having high or low bone turnover over a 4-year period, with $<10 \%$ being misclassified.

The organic matrix, more specifically type I collagen (which constitutes $90 \%$ of the bone organic matrix), is an important component of bone quality as it contributes to the micro-architecture and mechanical properties (i.e. flexibility and toughness) of bone (Ebeling \& Akesson, 2001; Felsenberg \& Boonen, 2005). A $35 \%$ decrease in the strength of the collagen network and $50 \%$ decrease in its toughness are associated with an age-related decline in bone strength (Burr, 2002). A decrease in overall collagen content is reported in osteoporotic bones, as is an abnormal value for reducible collagen cross-links:non-reducible collagen cross-links in bones of subjects prone to fractures (even in some subjects with normal BMD), suggesting that an abnormal bone collagen quality contributes to bone fragility (Banse et al. 2002; Paschalis et al. 2004). Thus, bone markers, particularly the resorption marker CTx, but also osteocalcin, which up to now have been used to monitor bone turnover or bone cell activity during therapy, have also been found to be useful in predicting fracture risk (Eastell et al. 2003; Khosla, 2003; P Delmas, unpublished results). Increased levels of bone-resorption markers predict hip, vertebral and non-vertebral fractures independently of BMD (Garnero et al. 2003b). Similarly, the reduction in vertebral fracture over 4 years is correlated with the 1-year decrease in bone turnover (Roux et al. 2005). At 6 months following commencement of bisphosphonate treatment, changes in urinary CTx and N-terminal telopeptide can explain $50-70 \%$ of the reduction in fracture risk (Roux et al. 2005). Likewise, osteocalcin levels at 2 years can account for $34 \%$ of the reduction in total vertebral risk fracture, greater than can be predicted from BMD measurement (Sarkar et al. 2004). Undercarboxylated osteocalcin is associated with increased risk of low BMD and increased risk of hip fracture (relative risk 5·3; Ebeling \& Akesson, 2001).

Thus, together bone-turnover markers and BMD greatly improve fracture-risk prediction as compared with their individual use (Eastell et al. 2003; Garnero \& Delmas, 2004; P Delmas, unpublished results). This finding is not surprising as BMD and bone markers are two separate and, at least partially, independent measures of bone quality (Felsenberg \& Boonen, 2005) that may be independently 
affected by therapy. Indeed, bone-turnover markers are only weakly correlated with BMD (Miller et al. 2005).

Although many of the studies on moderate alcohol intake and bone health that are outlined later have referred to measures of bone health assessed by BMD, some of them have also looked at bone markers. Together these assessments allow better conclusions to be drawn on the true association between alcohol intake and bone health at the population level.

\section{Moderate ingestion of alcoholic beverages and bone health}

Reports showing a beneficial effect of moderate alcohol intake on bone health are increasing. A small cross-sectional study conducted in the early 1990 s by Laitinen et al. (1991) has shown a positive correlation between alcohol intake and BMD in post-menopausal women at the lumbar spine $(r 0.44, P<0.01)$ and Ward's triangle (an area of the hip; $r 0 \cdot 34, P<0 \cdot 05)$. Post-menopausal women who drink alcohol (approximately 11-77 g/week) were found to have a higher BMD $\left(\mathrm{g} / \mathrm{m}^{2}\right)$ at the lumbar spine and Ward's triangle compared with non-drinkers; i.e. 1.094 (SD 0.080) $v$. 0.978 (SD 0.133) $(P<0.001)$ and 0.793 (SD 0.164) v. 0.690 (SD $0 \cdot 138)(P<0 \cdot 05)$ respectively. A subsequent study, which made adjustment for confounding factors such as age, BMI, smoking, regular exercise and use of oestrogen supplements in women, has also shown an alcohol-related increase in femoral neck BMD in men $(P<0 \cdot 01)$ and lumbar spine BMD in women $(P<0 \cdot 01)$ aged $\geq 45$ years (Holbrook \& Barrett-Connor, 1993). In addition, May et al. (1995) have confirmed that older men (aged 64-76 years) who consume alcohol have a higher trochanter (site of the femur that is rich in trabecular bone) BMD than nondrinkers after adjusting for age, weight, smoking, caffeine intake and physical activity. This positive effect of alcohol is supported by a population-based epidemiological study by Kroger et al. (1994), which has reported that moderate intake of alcohol significantly protects against the reduction in lumbar spine BMD peri-menopausally (odds ratio (OR) 0.6, $P<0.05$ ). Similarly, Smeets-Goevaers et al. (1998) have also found a protective effect of current alcohol intake ( $\mathrm{T}$ score $<-1 \mathrm{SD}$ ) in peri-menopausal women with low bone mass (OR 0.71 (95\% CI 0.61, 0.83)).

A bigger study by Felson et al (1995) has investigated the association between BMD and average alcohol intake over the previous 20 years in 1154 men and women (aged between 68 and 96 years) in the Framingham Cohort Study. Their results show that women with an average intake of $\geq 199 \mathrm{~g}$ alcohol/week $(29 \mathrm{~g} / \mathrm{d})$ have a higher BMD at the ultra-radius, proximal femur and lumbar spine, with the mean differences ranging between 4.2 and $13 \%$ compared with those consuming less than this amount after adjusting for age, weight, height, smoking and, in women, age at menopause and number of years of oestrogen use. The same pattern is also observed after additionally adjusting for caffeine intake, physical activity and vitamin D levels. Similarly, a prospective study from the Nurses' Health Study (Feskanich et al. 1999) has reported that Caucasian post-menopausal women consuming $\geq 75 \mathrm{~g}$ alcohol/week $(11 \mathrm{~g} / \mathrm{d})$ have a significantly greater lumbar spine BMD compared with abstainers $(P<0 \cdot 001)$, accounting for a $10-12 \%$ difference in BMD at this site. This finding is not related to the use of hormone-replacement therapy (HRT; being $1 \cdot 074 v .0 \cdot 965 \mathrm{~g} / \mathrm{cm}^{2}(P=0 \cdot 02)$ for current users of HRT and $0.894 v .0 .771 \mathrm{~g} / \mathrm{cm}^{2}(P=0.02)$ for non-users of HRT). A similar pattern was also found after additionally adjusting for physical activity, daily intake of $\mathrm{Ca}$, vitamin $\mathrm{D}$, protein and caffeine. As discussed later (p. 298) these data may provide important clues in delineating the true mechanism of action of moderate alcohol consumption on bone health.

In a cross-sectional study of 455 elderly women (aged 65-77 years) who were recruited for a multi-centre osteoporosis study, Rapuri et al. (2000) have reported a significantly higher BMD at the lumbar spine (7-16\%), mid-radius (8-14\%) and total body (5-12\%) in alcohol drinkers (consuming $>28.6 \mathrm{~g}$ alcohol/week or $4 \cdot 1 \mathrm{~g} / \mathrm{d}$ ) compared with non-drinkers after adjusting for height, weight, smoking, oestrogen use and other significant covariates. The most marked difference in BMD was found in moderate drinkers consuming $>28 \cdot 6-\leq 57 \cdot 2 \mathrm{~g}$ alcohol/week. This finding is consistent with the ' $\mathrm{U}$ ' or ' $\mathrm{J}$ '-shaped curve associated with health outcome and alcohol consumption, where the positive effect of alcohol on health is seen over a short consumption range (moderate intake; one to four servings per d) and the detrimental (or negative) effects with higher consumption (de Lorimier, 2000). Importantly, bone-marker analysis also undertaken in this study suggests that the higher BMD in moderate alcohol drinkers is chiefly associated with a reduction in the bone remodelling effects of alcohol. It should be noted that the apparent discrepancy between studies in absolute intakes of alcohol that are associated with positive effects on bone health are most likely a result of differing methodologies, as detailed earlier.

A larger French epidemiological study also published in 2000 (Ganry et al. 2000) has investigated the effect of alcohol on BMD after adjusting for potential confounders in 7598 woman aged $\geq 75$ years who were participants in the Epidemiologie de L'Osteoporose study. The results show a positive effect of moderate alcohol intake on trochanter $(P=0.03)$ and total body $(P=0.05)$ BMD after adjustment for age and weight. Lumbar-spine BMD was not reported in this work. Interestingly, the significance of the effect was found to be particularly notable when using the $\mathrm{Z}$ score $(P=0.0004$ for trochanter $\mathrm{Z}$ score and $P=$ 0.04 for total body $\mathrm{Z}$ score when adjusting for oestrogenreplacement therapy, current smoking status, usual physical activity, dietary $\mathrm{Ca}$, educational attainment, family monthly income and general health status). More rigorous adjustment for multiple comparisons shows that only moderate alcohol consumption (i.e. $11-29 \mathrm{~g} / \mathrm{d}$ ) is associated with a higher adjusted $\mathrm{Z}$ score BMD at the trochanter, which suggests a protective effect of moderate alcohol intake on trabecular bone loss. A study (Ilich et al. 2002) in 136 Caucasian post-menopausal women with a mean age of 68.6 years has made adjustment for even more potentially-confounding factors, including hormone status (serum PTH, vitamin D), body composition, age, dietary $\mathrm{Ca}$ intake, past smoking, caffeine and past physical activity. Again, for moderate alcohol drinkers (approximately 
$8 \mathrm{~g}$ alcohol/d on this occasion) an association with higher lumbar spine $(P<0 \cdot 001)$ and total body BMD $(P=0 \cdot 04)$ was still found. A recent small but tightly-controlled study (Williams et al. 2004) that used forty-two female monozygotic twin pairs who were classified as discordant for alcohol intakes again confirms a positive effect of moderate alcohol ingestion on adjusted BMD. Such studies are important as they control for genetic influences and allow the effect of independent environmental factors, in this case moderate alcohol ingestion, to be observed. In this study a positive association between alcohol intake and adjusted BMD was again found at the total spine and total hip sites $(P \leq 0.02)$ but no interaction was noted with either bone-formation markers (osteocalcin and alkaline phosphatase) or bone-resorption markers (urinary CTx). This result is in contrast to the findings of Rapuri et al. (2000) but, given the inter- and intra-individual variance in bone markers, it may simply be a result of low study numbers in the former or, possibly, an uncontrolled-for genetic influence in the latter.

A current longitudinal study is investigating the associations between nutrient intakes and bone loss during the menopausal transition in 891 subjects who took part in the Aberdeen Prospective Osteoporosis Screening Study. Using relatively robust energy-adjusted dietary intake measures (Macdonald et al. 2004), surprisingly, only moderate alcohol intake, but not other nutrient intakes, has been found to be a significant predictor of changes in lumbar spine BMD when adjusting for other important confounders $(P=0 \cdot 0002)$. These findings contrast with those of Bainbridge et al. (2004), who have reported higher femoral neck BMD in moderate alcohol drinkers aged 24-44 years $(P=0.0002)$ compared with abstainers but no effect at the lumbar spine. As noted earlier, this disparity highlights the need to be conservative in extrapolating findings from one population (in this case perimenopausal women) to another (in this case premenopausal women) and from different skeletal sites.

Although most studies have shown a positive effect of moderate alcohol intake on bone health in the elderly and in peri-menopausal and post-menopausal women, a few studies have reported no effect in these groups (Bauer et al. 1993; Shaw, 1993; Grainge et al. 1998). On the whole, however, these studies are small and/or have used linear trends or unusual methodology to examine associations.

In relation to younger subjects, and aside from the Bainbridge et al. (2004) study, New et al. (1997) have also reported a beneficial effect of moderate alcohol consumption on BMD in premenopausal women aged 45-49 years, but findings have not been consistent amongst the few studies that have been done; Laitinen et al. (1991) and Fehily et al. (1992) have shown a converse effect of alcohol intake, while Tudor-Locke \& McColl (2000) have reported no effect. Moreover, and again as noted earlier, the risk of female cancers in this group is likely to outweigh any benefit to bone from anything more than extremely modest alcohol consumption (Longnecker, 1993).

Surprisingly, compared with the micronutrient intakes that can be positively associated with BMD (e.g. vitamins $\mathrm{D}, \mathrm{C}, \mathrm{K}$ and $\mathrm{A}$, and minerals including $\mathrm{Ca}, \mathrm{Mg}, \mathrm{K}, \mathrm{Zn}$, $\mathrm{Cu}, \mathrm{Mn}, \mathrm{Sr}, \mathrm{F}, \mathrm{B}$ and Si (Marie \& Hott, 1986; Saltman \&
Strause, 1993; Reid \& New, 1997; Robins \& New, 1997); the role of $\mathrm{Si}$ is discussed in more detail later, see p. 304), the increase in BMD associated with moderate alcohol consumption is more consistently shown and the percentage change is comparable or higher (4-16 with moderate alcohol consumption $v$. 3-6 with $\mathrm{Ca}$ (if at all), 3-4 with $\mathrm{Mg}, 3-8$ with $\mathrm{K}$, 4 with vitamin D and 3-4 with vitamin C; Felson et al. 1995; Graafmans et al. 1997; Feskanich et al. 1999; Teegarden et al. 1999; Tucker et al. 1999; Macdonald et al. 2004). The most important question, therefore, is whether such an association with alcohol carries through to a reduced risk of osteoporotic fracture.

Cumming \& Klineberg (1994) have reported that alcohol intake is not associated with the risk of hip fracture in men and women aged $\geq 65$ years, and similar findings have been reported by Huang et al. (1996) using prospective data from the National Health and Nutrition Examination Survey I that included 2513 caucasian women aged $\geq 45$ years. However, the Dubbo Osteoporosis Epidemiology Study (Nguyen et al. 1996) in Australia has shown a lower risk of atraumatic fractures in 820 elderly men aged $\geq 60$ years who drank alcohol in moderation (OR 0.70 (95\% CI $0 \cdot 66,0 \cdot 81)$ ). Multiple regression analysis has suggested that the protective effect of moderate alcohol intake on the risk of fracture is mediated through its effect on BMD, as the relative risk is attenuated after adjusting for BMD. Subsequently, however, analysis of longitudinal studies in Copenhagen (Denmark) that included 17868 men and 13917 women (Hoidrup et al. 1999) has shown that moderate alcohol consumption of less than fourteen drinks per week in women and less than twenty-eight drinks per week in men is not associated with hip fracture compared with abstainers after adjusting for age, study of origin, smoking, physical activity, BMI and school education. There is some suggestion that those who prefer wine tend to have a lower risk of hip fracture (OR 0.77), although a more comprehensive analysis of potential confounders would be required to reach this conclusion. Similarly, Huopio et al. (2000) have reported no association between alcohol intake and the development of any particular type of osteoporotic fracture. However, a large population-based case-control study in Sweden, with a high rate of osteoporotic fracture, has reported an inverse association between moderate alcohol intake and risk of hip fracture in post-menopausal women (Baron et al. 2001). Subjects who drink alcohol in moderation were found to have a $20 \%$ lower age-adjusted risk of hip fracture (OR 0.80 (95\% CI 0.69, 0.93)), which was shown to be even lower (OR $0 \cdot 70(95 \%$ CI 0.60, 0.82)) after adjusting for other confounders (i.e. age, HRT, BMI and cigarette smoking). Interestingly, after classifying the types of alcoholic beverage, beer ( $4.5 \%$ alcohol) was found to provide the lowest risk of hip fracture after adjusting for confounders (OR 0.52) followed by wine (OR 0.67). These findings contrast with those of Hoidrup et al. (1999), who have suggested that a higher risk of hip fracture may occur in beer drinkers, perhaps because some heavy drinkers were included in this group. Kanis et al. (2005) have examined the risk of fracture in 16971 men and women from three prospective cohorts (The Canadian Multi-center Osteoporosis Study, The Dubbo Osteoporosis Epidemiology Study and The Rotterdam Study) and have found that 
the risk of osteoporotic fracture is not significantly increased in those who drink no more than two units/d.

Excessive alcohol consumption or alcohol abuse is associated with increased risk of morbidity and mortality, including liver disease, CVD, low bone density, hypertension and breast cancer (de Lorimier, 2000). There is also an increased risk of fractures due to increased risk of falls with alcohol consumption. Thus, unlike with excessive consumption of alcoholic beverages, there is no evidence that moderate consumption of alcohol leads to an increased risk of fracture. There are some limited data suggesting a decreased risk of fracture but, predominantly, the data suggest no overall risk. Nonetheless, the rather limited number of moderate-alcohol-focused studies, coupled with the potential for confounding factors, means that further work is still required in delineating the association between fracture risk and qualitative or quantitative aspects of moderate alcohol intake. Clearly, it is important to determine whether the generally positive association that is observed for moderate alcohol ingestion and BMD (especially in older individuals) is reflected in a reduced risk of fracture and how this reduction relates to total ethanol intake and to the different types of alcoholic beverage.

\section{Potential mechanisms}

A number of mechanisms have been proposed for the positive association between moderate alcohol consumption and BMD. Generally, it is considered that alcohol inhibits bone turnover (Rapuri et al. 2000; Turner et al. 2001), and the stimulation of calcitonin production (Rico, 1990) and/or a reduction in serum PTH (Laitinen et al. 1992; Rapuri et al. 2000; Ilich et al. 2002) have been proposed. However, studies on the effects of acute alcohol ingestion on circulating PTH levels in healthy volunteers have used 35-90 g ethanol in a short period of time, which is not generally in line with moderate consumption (Laitinen et al. 1992; Garcia-Sanchez et al. 1995). Similar concerns can be voiced over work showing ethanol-induced changes to calcitonin concentrations. In fact, in preliminary volunteer studies (Powell et al. 2005b) it has recently been shown that serum PTH and calcitonin levels are not significantly changed following moderate ethanol ingestion. Serum levels of intact PTH were found to decline following $\mathrm{Ca}$ ingestion (positive control) but to remain unchanged compared with normal diurnal variation following ingestion of $<28 \mathrm{~g}$ ethanol. Similarly, serum calcitonin levels were found to be unchanged in response to ethanol consumption. Nonetheless, it has been possible to show that moderate ethanol ingestion does appear to acutely inhibit bone resorption, based on suppression of circulating CTx in volunteers (Powell et al 2005b). Although unrelated to calcitonin and PTH, mechanisms that could, in part, be related to the energy content of ethanol continue to be investigated. Since no other data are currently available on acute mechanisms of ethanol, the remaining text will focus on the alcohol-oestrogen-bone relationship and on the non-ethanol components of alcoholic beverages that could be related to bone health.

\section{Oestrogenic effects of alcohol: any relevance to bone mineral density?}

Oestrogens play a key role in skeletal protection, as emphasised by bone loss in oestrogen-deficient states such as post-menopausally and following ovariectomy. Cellular mechanisms appear to be mediated through oestrogen receptors (ER) $\alpha$ and $\beta$, both of which are expressed in bone, as well as through non-ER $\alpha$ and $\beta$ pathways (Ioannidis et al. 2002; Shearman et al. 2004). Oestrogenic effects of alcohol are well recognised, and while there is no suggestion that ethanol or its metabolites (e.g. acetaldehyde) have oestrogen-mimetic properties, three other possibilities have been widely considered.

First, ethanol consumption may increase ER activity, especially $E R \alpha$, in a number of tissues. However, while this effect is well recognised with abusive alcohol consumption (Colantoni et al. 2002), its extension to moderate consumption is not so clear, at least in vivo. Nonetheless, in in vitro studies in human breast cancer cell lines (Fan et al. 2000; Singletary et al. 2001) moderate to high levels of ethanol stimulate $\mathrm{ER} \alpha$ activity, which is in part driven by increased ER $\alpha$ expression (Fan et al. 2000; Singletary et al. 2001), but suppression of the breast cancer susceptibility gene BRCA1, which is an inhibitor of $\mathrm{ER} \alpha$ activity, also occurs (Fan et al. 2000). Whether these observations can be extended to moderate alcohol intake and effects on bone cells in vivo remain to be determined. Second, tissue exposure to oestrogens in part occurs through aromatisation of androgens to oestrogens (and in normal males and post-menopausal females exclusively through this pathway). A number of cellular and animal studies have indicated that alcohol can promote such aromatisation (Purohit, 2000). Again, however, in vivo studies suggest that only heavy chronic alcohol intake can increase circulating oestrogen in this fashion (Purohit, 2000). This finding is consistent with the observation that alcohol ingestion only notably increases circulating oestradiol in post-menopausal women taking oestrogen-replacement therapy (Purohit, 1998), indicating a direct oestrogenic effect rather than an aromatisation effect. Indeed, it is direct inhibition of oestradiol catabolism that is the third and likely dominant influence of moderate ethanol consumption on oestrogens in vivo. Premenopausal women taking oral contraceptives exhibit alcohol-induced $(0.5 \mathrm{~g} / \mathrm{kg})$ increases in oestradiol (Sarkola et al. 1999), while the majority of studies indicate that even in the absence of supplemental oestrogens there is a slight but significant effect of moderate alcohol ingestion on circulating oestradiol levels in this population (Muti et al. 1998; Ginsburg, 1999; Martin et al. 1999). The influence of genotype on alcohol metabolism (Coutelle et al. 2004) and the difficulties in capturing a true record of alcoholic beverage intake (Gavaler \& Love, 1992) and then being able to relate such factors to oestradiol levels that naturally cycle means that further work is required to delineate the true influence of moderate alcohol ingestion on oestradiol levels in premenopausal women. This approach may help in understanding bone or cardiovascular health, but it is especially important in determining the link between alcohol intake, oestrogens and female cancers (Coutelle 
et al. 2004). In post-menopausal women or in men, who have lower natural levels of oestradiol than premenopausal women, the evidence for an effect of moderate alcohol ingestion is more limited. While the majority of studies show no effect of alcohol on oestradiol levels (Ginsburg et al. 1996; Ginsburg, 1999; Sierksma et al. 2004), the two studies that do show an effect for post-menopausal women are either inconsistent amongst their subgroups (Purohit, 1998) or suggest beverage specificity (i.e. positive for wine but not other beverages; Purohit, 1998). In relation to this latter observation, it is interesting to note that in the absence of ethanol oestrogenic activity of wine extracts has been demonstrated (Klinge et al. 2003) while that of beer, for example, appears to be minimal (Promberger et al. 2001). Furthermore, Henk Hendrik's group (Sierksma et al. 2004) have shown in a carefully-controlled intervention study that beer ingestion for 3 weeks in men and post-menopausal women $(30 \mathrm{~g}$ ethanol/d) has no effect on plasma oestradiol levels. Further work is therefore required to determine whether wine drinking may differ in this respect, because of some non-ethanol components.

In post-menopausal women taking HRT moderate to high ethanol consumption has been observed to affect circulating oestradiol levels (Purohit, 1998; Ginsburg, 1999). In subjects receiving high-dose oral HRT (1 mg oestradiol $/ \mathrm{d})$ alcohol ingestion $(0.7 \mathrm{~g} / \mathrm{kg}$ in a single dose) leads to a peak 3-fold increase in oestradiol, and levels remain above baseline for $5 \mathrm{~h}$. There is no effect in women not taking HRT (Ginsburg et al. 1996).

Taken together these studies on alcohol ingestion and circulating oestradiol levels are consistent with three observations. First, alcohol acutely inhibits the rate at which oestradiol is catabolised, perhaps as a result of ethanolmediated increases in hepatic NADH:NAD (Sarkola et al. 1999), such that higher levels of oestradiol and/or higher levels of alcohol intake show the most effect. Second, effects for moderate ingestion are probably relatively short lived and, therefore, observations on such interactions need to take account of the timing of alcohol ingestion and the natural fluctuations in oestradiol levels. Third, other components of alcoholic beverages, especially wine, may have oestrogen-mimetic properties, but whether in vivo these components can markedly alter the rate of catabolism of natural oestradiol, or add to the oestrogenic pool, remains to be determined.

How relevant are these observations to bone? Based on the unequivocal role of oestrogens in protecting against bone loss, the oestrogenic potential of alcohol and the oestrogen-alcohol axis in female cancers it is tempting to speculate that moderate alcohol ingestion is associated with increased BMD because of its pro-oestrogenic activity. However, evidence argues against this explanation. First, a critical review of the evidence suggests that the oestrogenic effects of alcohol are mainly associated with inhibition of oestradiol catabolism, which should be exaggerated at higher oestradiol levels. However, in two major studies that have explored alcohol-BMD interactions in post-menopausal women (Feskanich et al. 1999; Ganry et al. 2000) the results have been found to be unrelated to the use of oestrogen-replacement therapy. Even if the alternative argument is considered, i.e. that moderate alcohol intake promotes some oestrogen activity (i.e. anabolic instead of anti-catabolic), then the same data (Feskanich et al. 1999; Ganry et al. 2000) do not support a marked influence on bone because oestrogen-replacement therapy would be expected to overwhelm the ethanol effect, which is clearly not observed. Indeed, any notion that the moderate effect of alcohol on bone is best observed under conditions of low oestradiol status is probably misplaced and, as noted earlier, is more likely to be related to the fact that post-menopausal women and/or the elderly have simply been the best-studied groups for diet-BMD interactions because they are the main targets for assessment and treatment of oesteopenia and osteoporosis. Finally, it is possible that alcohol has differential effects on the genotoxic and hormonal pathways of oestrogen, so extrapolation between pro-carcinogenic activity and skeletal or cardiovascular protection may not be valid (Feskanich et al. 1999). Thus, in summary, it seems probable that moderate alcohol consumption can to some extent influence circulating oestrogens, or even androgens (Gavaler et al. 1991; Katsouyanni et al. 1991; Hankinson et al. 1995), but critical review of existing data does not then support a knock-on effect in terms of bone health.

\section{Phenolic and antioxidant aspects of alcoholic beverages}

Alcoholic beverages contain a number of phenolic constituents (many of which are also found in some fruit and vegetables) that may impact on bone health. Wine contains several polyphenols that are derived from the grapes or from the wood or yeast during vinification. Although wine, particularly red wine, is often the principal alcoholic beverage discussed in relation to phenolics, beer is also a rich source of polyphenols, several of which are derived from the hops added during the brewing process. Typically, polyphenols are understood to be antioxidants, although some may also have oestrogen-mimetic properties, and their effects have principally been studied in relation to CVD and cancer, but emerging evidence from in vitro studies suggests that they may also affect bone.

Several classes of phenolic compounds have been identified in alcoholic beverages, and they can be broadly classified into different groups (for examples, see Table 2). Resveratrol, a non-flavonoid stilbene, is probably the bestknown red wine polyphenol. However, other phenolic compounds are present in higher concentrations, including conjugates of flavonols (rutin, quercetin, myricetin and others), flavanols (catechin and related compounds), anthocyanins (delphinidin and cyanidin), hydroxycinnamic acids (caffeic acid, coumaric acid) and gallic acid (Burns et al. 2001; Zafrilla et al. 2003). White and/or rose wines also contain several of these compounds, although generally at lower concentrations when compared with red wine, with the possible exception of hydroxycinnamic acids (Carando et al. 1999; Dugo et al. 2003; Lugasi \& Hovari, 2003; Zafrilla et al. 2003). Concentrations of phenolic compounds vary widely, even within a similar type of wine, because of differences in grape varieties and storage time and different approaches to the vinification process. 
Table 2. Examples of phenolic compounds found in alcoholic beverages

\begin{tabular}{|c|c|c|c|c|c|}
\hline $\begin{array}{l}\text { Flavonols and } \\
\text { related glycosides }\end{array}$ & Flavanols & Anthocyanins & $\begin{array}{l}\text { Prenylflavonoids and } \\
\text { related compounds }\end{array}$ & $\begin{array}{l}\text { Hydroxycinnamates and } \\
\text { other phenolic acids }\end{array}$ & Stilbenes \\
\hline $\begin{array}{l}\text { Myricetin } \\
\text { Quercetin } \\
\text { Kaempferol } \\
\text { Isorhamnetin } \\
\text { Rutin } \\
\text { Astragalin }\end{array}$ & $\begin{array}{l}\text { Proanthocyanidins } \\
\text { Catechin } \\
\text { Epigallocatechin gallate } \\
\text { Epicatechin }\end{array}$ & $\begin{array}{l}\text { Delphindin } \\
\text { Cyanidin } \\
\text { Petunidin } \\
\text { Peonidin } \\
\text { Malvidin }\end{array}$ & $\begin{array}{l}\text { Xanthohumol } \\
\text { Isoxanthohumol } \\
\text { Desmethylxanthohumol } \\
\text { Humulone } \\
\text { Prenylnaringenins } \\
\text { Geranylnaringenins }\end{array}$ & $\begin{array}{l}\text { Caffeic acid } \\
\text { Caffaric acid } \\
\text { Coumaric acid } \\
\text { Ferulic acid } \\
\text { Vanillic acid } \\
\text { Sinapic acid } \\
\text { Hydroxybenzoic acid }\end{array}$ & Resveratrol \\
\hline
\end{tabular}

Beer contains several classes of phenolic compounds, including flavonols (such as quercetin, kaempferol and myricetin), proanthocyanidins, flavanols (including catechins) and various phenolic acids (Stevens \& Page, 2004; Tedesco et al. 2005; Nardini et al. 2006). Beer is also the most important dietary source of xanthohumol (XH) and its related prenylflavonoids (Stevens \& Page, 2004; Gerhauser \& Frank, 2005). XH exerts anti-carcinogenic effects in vitro and in vivo. In addition in vitro, it has anti-microbial properties and inhibits the formation of triacylglycerols (reviewed in Gerhauser \& Frank, 2005). It is the major prenylflavonoid found in hops, but several others exist, e.g. desmethylxanthohumol, humulone and $3^{\prime}$-geranylnaringenein. These compounds are usually converted into their isomeric flavanones, isoXH (the principal dietary prenylflavonoid), prenylnaringenins and geranylnaringenins by thermal isomerisation during the brewing process (Stevens et al. 1999). As with wine, the phenolic content of different beers varies widely, probably depending on the type of beer, source and concentration of hops and the brewing process (Stevens \& Page, 2004; Tedesco et al. 2005).

Although little is known about the action of phenolic compounds on the skeleton, recent evidence, mainly from in vitro studies, suggests that they are worth discussing in relation to bone health. Muhlbauer et al. (2003) have observed that $1 \mathrm{~g}$ red wine extract/d inhibits bone resorption in rats compared with controls, measured by urinary excretion of ${ }^{3} \mathrm{H}$-labelled tetracycline from prelabelled rats. Interestingly, $1 \mathrm{~g}$ beer extract/d was found to have no effect. However, the polyphenol content in the extracts was found to vary considerably (equivalent to $40-161 \mathrm{mg} / \mathrm{d}$ for red wine but only $2.4-3.9 \mathrm{mg} / \mathrm{d}$ for beer), which may explain this difference. Individual phenolic compounds have also been related to bone activity and these compounds will therefore be discussed.

\section{Catechin and related flavanols}

(+)-Catechin and some related flavanols modulate bone metabolism in vitro and in vivo. In embryonic mouse calvariae cultures pretreatment with $(+)$-catechin inhibits PTH-driven and retinoic acid-driven bone resorption (Delaisse et al. 1986). In addition, in the MC3T3 E1 murine osteoblast cell line, $(+)$-catechin $(10 \mu \mathrm{M})$ exerts anabolic effects, by doubling alkaline phosphatase activity and significantly decreasing the production of the bone-resorbing cytokines TNF $\alpha$ and IL-6 and inhibiting apoptosis (Choi \& Hwang, 2003). Stoss et al. (1979) have also demonstrated in a small study that supplementation with (+)-catechin $(25-40 \mathrm{mg} / \mathrm{kg}$ body weight, which is much higher than would be derived from food sources but appears to be well tolerated) has beneficial clinical effects in osteogenesis imperfecta. In four affected girls aged 4-12 years who were given $(+)$-catechin for several months the frequency of fractures was found to be reduced. However, there have been no larger follow-up studies or studies in populations with, or at risk of, osteoporosis.

Another related flavanol, epigallocatechin gallate (EGCG), also exerts effects on bone in vitro, although results have been inconsistent. In mouse calvarial primary osteoblastic cells EGCG $(20 \mu \mathrm{M})$ abolishes Porphyromonas gingivalis-induced matrix metalloprotease- 9 expression, which is involved in bone resorption (Yun et al. 2004). In the same study it was found that EGCG inhibits osteoclast formation (by $68 \%$ ) in a co-culture system of bone marrow cells and calvarial primary osteoblastic cells, without affecting cell viability. Nakagawa et al. (2002) have also reported inhibitory effects of EGCG on murine osteoclasts in a co-culture model. However, in contrast to the findings of Yun et al. (2004) cell viability was found to be affected, even at the lowest dose of $12.5 \mu \mathrm{M}$-EGCG. In contrast to all these studies Yamaguchi \& Jie (2001) have observed no positive effects of either catechin or EGCG $(0 \cdot 1-100 \mu \mathrm{M})$ on either bone calcification or alkaline phosphatase activity in femoral diaphyseal and metaphyseal tissues of rats in vitro. The differences in results between the studies do not appear to be associated with the concentrations used, but may be a result of the different cell-culture models or the different outcomes measured. Human studies are required to determine if these flavanols exert modulatory effects on bone in vivo.

\section{Rutin, quercetin and kaempferol}

Several flavonols found in alcoholic beverages have been reported to modulate bone cell activity in vitro, although very little is known about their effects in vivo. In ovariectomised rats rutin supplementation for 3 months prevents the loss of femoral BMD induced by ovariectomy. In addition, following supplementation plasma osteocalcin concentration is higher and urinary excretion of deoxypyridinoline and $\mathrm{Ca}$ is lower in the rutin-supplemented group than in the control ovariectomised rats (Horcajada-Molteni et al. 2000). These in vivo effects suggest that either rutin, or its active metabolites quercetin and isorhamnetin, may exert modulatory effects on bone cells. Indeed, results from in vitro studies (Wattel et al. 2003, 2004; Woo et al. 2004; 
Rassi et al. 2005) suggest that both rutin and quercetin may directly affect bone cells, particularly osteoclasts. Quercetin has been reported to induce apoptosis in primary rabbit or porcine osteoclasts (Wattel et al. 2003; Rassi et al.

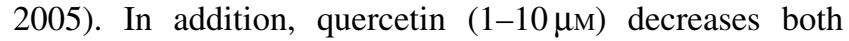
osteoclast formation and activity in murine primary macrophage colony-stimulating factor-dependent osteoclast progenitors and in RAW 264.7 macrophages treated with receptor activator of NF- $\mathrm{KB}$ (RANK) ligand, as well as human peripheral blood mononuclear cells differentiated with macrophage colony-stimulating factor and RANK ligand (Wattel et al. 2004; Woo et al. 2004). Moreover, Rassi et al. (2005) have recently demonstrated in a porcine bone-marrow model that even low nanomolar concentrations of quercetin or rutin significantly inhibit osteoclast formation and activity similar to $17 \beta$ oestradiol. Kaempferol $(1-6 \mu \mathrm{M})$, another flavonol found in alcoholic beverages, also induces apoptosis and inhibits bone resorption activity in primary rabbit osteoclasts even at concentrates of less than $1 \mu \mathrm{m}$ (Wattel et al. 2003). The action of flavonols on bone is not limited to effects on osteoclasts. Both kaempferol and quercetin have also been reported to stimulate alkaline phosphatase activity in human MG63 osteoblasts at $50 \mu \mathrm{m}$ for $48 \mathrm{~h}$ this results in a 1.5- and 1.7fold increase, respectively (Prouillet et al. 2004). In contrast, Yamaguchi \& Jie (2001), who found no effects with EGCG or catechin in their bone model, have also reported that quercetin $(0 \cdot 1-100 \mu \mathrm{M})$ has no effects on either bone calcification or alkaline phosphatase activity in femoral diaphyseal and metaphyseal tissues of rats in vitro. However, overall, these in vitro studies suggest that some of the flavonols found in wine and beer may exert effects on bone; in vivo studies are required for confirmation.

\section{Resveratrol}

In animal studies supplementation with resveratrol leads to varying effects on bone. In a recent study (Liu et al. 2005) ovariectomised rats supplemented with $0.7 \mathrm{mg}$ resveratrol per $\mathrm{kg}$ body weight for 3 months were found to have a higher epiphysis BMD and femoral bone $\mathrm{Ca}$ content compared with ovariectomised controls. Resveratrol supplementation also inhibits bone loss, increases hydroxyproline content and femur bone strength in ovariectomised strokeprone spontaneously-hypertensive rats compared with ovariectomised controls (Mizutani et al. 2000). In contrast to the findings of these studies, resveratrol has been shown to have no effect on radial bone growth (periosteal bone formation and mineral apposition rates) at the tibia-fibula synostosis in weanling rats (Turner et al. 1999). In in vitro rat and chicken osteogenesis models resveratrol has been reported to reverse the effects of arylhydrocarbons, which inhibit osteoblast differentiation and markers of differentiation (including alkaline phosphatase, collagen type 1, osteopontin and bone sialoprotein) and reduce mineralisation (Singh et al. 2000; Andreou et al. 2004). In addition, resveratrol (1-100 nM) increases DNA synthesis, alkaline phosphatase and prolyl hydroxylase activity in murine MC3T3E1 osteoblasts, suggesting that it stimulates osteoblast proliferation and differentiation (Mizutani et al. 1998). In these cells and in human MG63 cells resveratrol also inhibits prostaglandin $\mathrm{E}_{2}$ production, which decreases alkaline phosphatase activity and, concomitantly, increases acid phosphatase activity and enhances osteoclast differentiation from stem cells (Boyan et al. 2001). Overall, the in vitro studies to date support a role for resveratrol in modulation of bone cell activity.

\section{Prenylated flavonoids}

Little is known about the effects on bone health of prenylated flavonoids, which are found in beer. 8-Prenylnaringenin $(\mathrm{PN})$ is one of the most abundant prenylflavonoids in beer and has been reported to be a potent phyto-oestrogen in vitro (Stevens \& Page, 2004). In a rat model 8-PN has been shown to inhibit ovariectomyinduced loss of BMD in the proximal tibia and suppress urinary excretion of the bone markers hydroxyproline, pyridinoline and deoxypyridinoline (Miyamoto et al. 1998). 8-PN increases alkaline phosphatase activity in vitro in normal human fetal osteoblasts $(0.5 \mu \mathrm{m}$ results in a 2.5 fold increase) (Effenberger et al. 2005). In addition, 8-PN and, to a lesser extent, 6-PN, $\mathrm{XH}$ and isoXH increase alkaline phosphatase gene expression in U2-human osteosarcoma cells. IL-6, a marker of bone resorption, is also down regulated in these cells by 8-PN and 6-PN; a process that is ER $\alpha$ dependent. In contrast, 8-PN may not affect osteoclast activity, since it has no effect on bone resorption in a pit-formation assay (Tobe et al. 1997). Other constituents of hops, including XH and humulone, are inhibitory in this bone-resorption model (with half maximal inhibitory concentrations of approximately $1 \mu \mathrm{M}$ and $6 \mathrm{~nm}$ respectively). Humulone also exerts effects in osteoblasts; for example, in MC3T3-E1 cells humulone suppresses TNF $\alpha$-dependent cyclooxygenase- 2 transcription, which plays an important role in prostaglandin E2 production (Yamamoto et al. 2000). These limited in vitro studies suggest that prenylflavonoids also exert effects on bone cells.

\section{Potential mechanisms of action of polyphenols in bone}

Phenolic compounds may act via several mechanisms to exert effects on bone (Fig. 1). Several polyphenols found in alcoholic beverages, e.g. EGCG, resveratrol, quercetin, kaempferol and the prenylflavonoids discussed earlier, bind to ER $\alpha$ and ER $\beta$ (Bowers et al. 2000; Goodin et al. 2002; Wattel et al. 2003; Prouillet et al. 2004; Rassi et al. 2005) and, therefore, may directly modulate gene transcription through these receptors. However, the mechanisms are complex as, depending on the environment, the type of ER ( $\alpha$ or $\beta$ ) that they engage or the concentration or type of phenolic compound used, they may act either as oestrogen agonists or antagonists and may exert different oestrogenic activities. For example, although resveratrol binds ER $\alpha$ and ER $\beta$ with comparable affinity in CHO-K1 cells, resveratrol exerts oestrogenic activity through ER $\beta$ but both agonist and antagonist activities through ER $\alpha$ (Bowers et al. 2000; Goodin et al. 2002; Wattel et al. 2003; Prouillet et al. 2004; Rassi et al. 2005). In the human U2-osteosarcoma cell line, although XH, isoXH, 8-PN and 6-PN all bind ER $\alpha$ and ER $\beta, 8-\mathrm{PN}$ shows no preferential affinity for either receptor while all the 


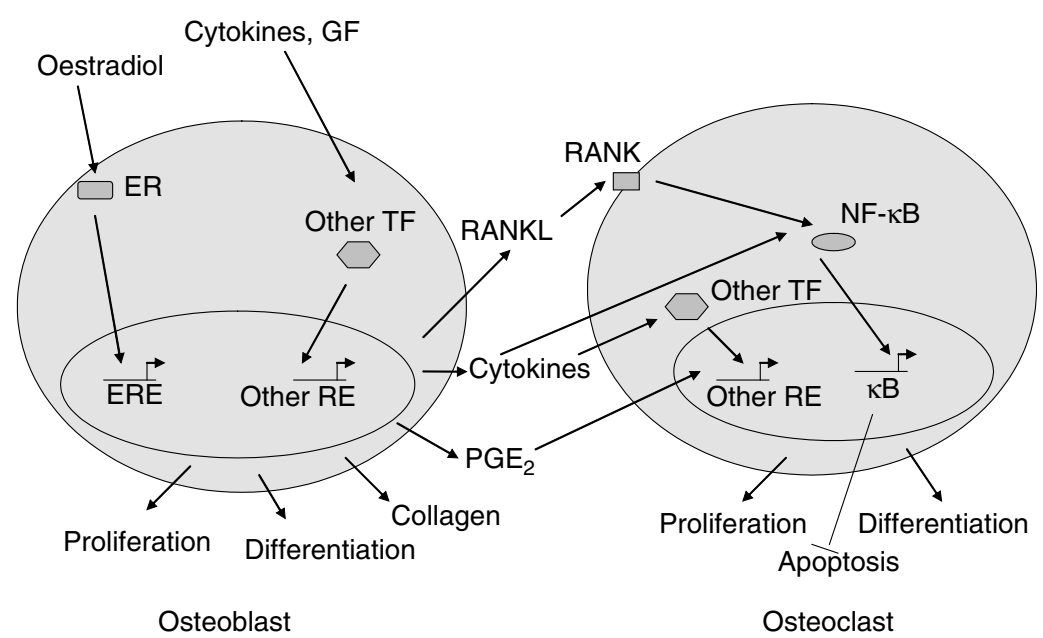

Fig. 1. Signalling pathways in osteoblasts and osteoclasts that are potentially regulated by phenolic compounds in alcoholic beverages. Polyphenols may bind to oestrogen receptors $(E R)$ in bone cells, resulting in increased or decreased oestrogenic activity. They may regulate other signalling pathways leading to the activation of transcription factors (TF), including NF-KB, activator protein-1, NF-IL6 and NF-E2related factor-2, and ultimately to changes in proliferation, differentiation, cytokine secretion and collagen formation. ERE, oestrogen-response element; GF, growth factor; $\mathrm{PGE}_{2}$, prostaglandin $\mathrm{E}_{2}$; RANK, receptor activator of NF- $\mathrm{KB}$; RANKL, RANK ligand; $R E$, response element.

other compounds preferentially bind ER $\beta$ (Effenberger $e t$ al. 2005). In addition, binding to the different ER does not necessarily lead to oestrogenic activity. For example, although both EGCG and epicatechin gallate bind to ER $\alpha$ and ER $\beta$ in MCF-7 breast carcinoma cells, only EGCG exerts ERmediated gene expression in these cells (Goodin et al. 2002).

As well as direct ER binding, several polyphenols exert non-ER-mediated cellular activities. Redox signalling pathways in osteoblasts and osteoclasts may be regulated by polyphenols, as the majority of these compounds display antioxidant activities. Catechins, for example, have been reported to inhibit oxidative stress in cultured rat calvarial osteoblasts (Park et al. 2003). In addition, reactive oxygen species are important secondary messengers in RANK ligand activation of the transcription factor NF- $\kappa \mathrm{B}$ in osteoclasts (Ha et al. 2004). NF- $\kappa$ B plays a key role in inflammation, proliferation and inhibition of apoptosis. It regulates the production of osteoclastogenic cytokines and prostaglandins in osteoblasts and stimulates osteoclast activation and differentiation (Agarwal et al. 2003; Chae et al. 2004; Boyce et al. 2005). Several polyphenols found in alcoholic beverages, including EGCG, resveratrol, quercetin and humulon, inhibit NF- $\mathrm{KB}$ (Yamamoto et al. 2000; Yang et al. 2001; Estrov et al. 2003; Wattel et al. 2004), although few studies have examined these effects in bone cells. Yamamoto et al. (2000), however, have demonstrated that humulon suppresses TNF-dependent cyclooxygenase-2 transcription in MC3T3-E1 cells via the transcription factor $\mathrm{NF}-\kappa \mathrm{B}$ and another transcription factor, NF-IL6. In RAW cells pretreatment with quercetin inhibits RANK ligand-induced osteoclast formation and NF- $\kappa \mathrm{B}$ and activator protein 1 activation (Wattel et al. 2004). In addition, Rassi et al. (2005) have observed that quercetin induces apoptosis in osteoclasts by caspase activation.
These effects may be mediated via NF- $\kappa \mathrm{B}$, although this aspect was not investigated. It should be noted that even within the same bone cell type different polyphenols of the same class can exert varying mechanisms of action. For example, quercetin and rutin (a glycoside of quercetin) have both been shown to inhibit osteoclast activation, yet rutin acts by reducing RANK protein while quercetin induces apoptosis in the same cell model (Rassi et al. 2005). Recent research also suggests that many of these phenolic compounds activate intracellular antioxidants and cyto-protective enzymes, which may result in antiinflammatory effects in bone leading to prevention of bone loss. For example, resveratrol and EGCG have been reported to induce the cellular antioxidant haem oxygenase-1 via the activation of the transcription factor NF-E2-related factor-2 (Chen et al. 2005). In addition, several prenylated flavonoids have been reported to activate NADPH quinone reductase and other phase II cyto-protective enzymes (Stevens \& Page, 2004). Several of these enzymes are regulated by NF-E2-related factor-2 (Chen \& Kunsch, 2004). Activation of NF-E2-related factor-2 and haem oxygenase1 leads to anti-inflammatory effects in vitro and in vivo in vascular models (Soares et al. 2005; Chen et al. 2006). Inflammation is an important trigger of osteoclastogenesis and, recently, Zwerina et al. (2005) have demonstrated the anti-inflammatory effects of haem oxygenase- 1 in bone, as haem oxygenase-1 expression suppresses osteoclastogenesis in vitro and in vivo. Furthermore, NF-E2-related factor-2 is activated during osteoblast differentiation (Beck et al. 2001, 2003; Wu et al. 2005). Finally, some of these compounds may exert other effects independent of gene transcription; catechins, for example, have been found to increase collagen stability, although the mechanism is unclear (Madhan et al. 2005). 


\section{Intakes of phenolic compounds with moderate alcohol consumption: are they sufficient to induce effects in bone?}

Virtually no studies have reported effects of either alcoholic beverage extracts or the individual phenolic components on bone health in human subjects. Although the studies discussed earlier suggest that phenolic compounds from wine and beer can affect bone cells in vitro, it is difficult to determine if moderate alcohol consumption provides sufficient concentrations of these compounds to affect BMD and metabolism in vivo. As previously discussed, there are difficulties in assessing moderate alcohol intake, and the concentrations of phenolic compounds vary considerably among alcoholic beverages, even when comparing similar wines from the same region or beers from the same country (Carando et al. 1999; Andrade et al. 2001; Stevens \& Page, 2004; Tedesco et al. 2005). As with all dietary studies that relate to polyphenols, bioavailability remains an issue (for reviews of bioavailability and bioefficacy of polyphenols described in human subjects, see Manach et al. 2005; Williamson \& Manach, 2005). The bioavailability of phenolic compounds is generally considered to be low. Several phenolic compounds are metabolised in the gut and potentially the liver, resulting in methyl, sulfate or glucuronic acid conjugates, and they are rapidly excreted (Ruefer et al. 2005; Williamson \& Manach, 2005). Following oral administration, plasma concentrations of polyphenols are generally $\leq 5 \mu \mathrm{M}$. Among the few studies examining effects on bone in vivo, Horcajada-Molteni et al. (2000) have reported that rats fed high concentrations of rutin $(2.5 \mathrm{~g}$ rutin per $\mathrm{kg}$ diet $)$ achieve a mean plasma concentration of $9.5 \mu \mathrm{M}$-rutin metabolites, with isorhamnetin the highest at $6 \cdot 8 \mu \mathrm{M}$. The bioavailability of trans-resveratrol is also relatively low; a $25 \mathrm{mg}$ oral dose given to healthy men and women results in trace amounts in plasma, and metabolites peak 30-60 min later at concentrations of about $2 \mu \mathrm{M}$ (Goldberg et al. 2003; Walle et al. 2004). There is a lack of studies on the absorption, metabolism and excretion of $\mathrm{XH}$ and its metabolites in human subjects. When $\mathrm{XH}$ is fed to rats twentytwo metabolites are isolated from faeces (including isoXH) and most of the parent $\mathrm{XH}$ is recovered (Nookandeh et al. 2004), suggesting that bioavailability is low. Nonetheless, low levels of XH monoglucuronides have been detected in plasma after administration of XH in male rats (Stevens \& Page, 2004) and the bioavailability of other prenylflavonoids is unclear. Several questions remain to be answered in relation to the bioavailability of phenolic compounds found in alcoholic beverages. Further studies are required to examine their metabolism in the gut and the kinetics of metabolism. Although plasma levels may be low following oral administration, few studies have investigated whether they accumulate in tissues or whether their metabolites may be active, and research in the bone field is in the early stages. Finally, it should also be remembered that studies carried out with single doses may not be representative of dietary exposure where tissue accumulation could be postulated through gradual chronic exposure. Indeed, Suganuma et al. (1998) have demonstrated that after a single dose of EGCG low level accumulation occurs in several tissues, but after a second dose a 4-6-fold increase above the single dose is detected in tissues.

Higher intakes of polyphenol-rich foods have been associated with protective effects in CVD and cancer. Indeed, moderate alcohol consumption has been consistently associated with $20-30 \%$ reductions in risk for coronary artery disease (Klatsky, 2003), although, as with bone, it is unclear whether red wine or beer polyphenols confer any additional effect to that of ethanol. As moderate red wine consumption ( $375 \mathrm{ml}$ red wine/d for 2 weeks) inhibits oxidative stress in normal healthy volunteers (Tsang et al. 2005), and this outcome is likely to be associated with the polyphenol content, it is possible that there may be additional effects. Several research groups (New et al. 1997; Tucker et al. 1999; McGartland et al. 2004; Prynne et al. 2006) have observed that higher intakes of fruit and vegetables, which are also a rich source of phenolic compounds, are positively associated with BMD. Clearly, more work is required with specific polyphenolic compounds.

Thus, in summary, phenolic compounds that are present in alcoholic beverages appear to have the potential to affect bone, as indicated by evidence from the in vitro studies described earlier. These effects may occur through various signalling pathways, some of which may be oestrogen dependent. Further studies are required to clarify the issues of bioavailability and metabolism of these compounds, and more analysis needs to be carried out to determine concentrations in different wines and beers. In addition, further in vitro studies are required using metabolites of these compounds at concentrations found in plasma and/or tissues, as well as in vivo studies to determine their effects on bone. Thus, it is currently unclear whether polyphenolic compounds contribute to the increase in BMD that is associated with moderate alcohol consumption.

\section{Silicon}

Dietary $\mathrm{Si}$, which is absorbed as orthosilicic acid $\left(\mathrm{Si}(\mathrm{OH})_{4}\right)$, may be beneficial for growth and development of bone and other connective tissues (Jugdaohsingh et al. 2004). The role of $\mathrm{Si}$ in bone health has recently been reviewed (Sripanyakorn et al. 2005), and will be only briefly summarised here. However, as it has also been shown that certain alcoholic beverages, especially all beers, are high in Si (Sripanyakorn et al. 2004; Powell et al. 2005a), the potential for alcohol-BMD associations to be partly mediated through $\mathrm{Si}$ intakes is considered.

\section{Alcoholic beverages as dietary silicon sources}

Typically, between 20 and $40 \mathrm{mg} \mathrm{Si}$ per adult perd is ingested from Western diets (Pennington, 1991; Jugdaohsingh et al. 2002). Foods derived from plants rather than animals provide the highest sources of dietary Si (Varo \& Koivistoinen, 1980; Pennington, 1991; Powell et al. 2005a), because certain plants, especially cereals, take up and accumulate $\mathrm{Si}$ at high levels (Sangster et al. 1986; Epstein, 1999). Amongst plant-based foods, whole grains have the highest level of $\mathrm{Si}$, especially oats and barley, and rice bran and wheat bran and, not surprisingly, products 
made from the grains are also high in $\mathrm{Si}$ (Powell et al. 2005a; Pennington 1991). In particular, very high levels of $\mathrm{Si}$ are found in beer, which is made from macerated wholegrain barley (Sripanyakorn et al. 2004; Powell et al. 2005a). Recently, a mean concentration of $19 \cdot 2$ (SD 6.6) $\mathrm{mg} \mathrm{Si} / \mathrm{l}$ was reported from an analysis of seventy-six different beers (Sripanyakorn et al. 2004). Si levels in the different beers were not found to be significantly different by alcohol content, geographical origin or type of beer (Sripanyakorn et al. 2004; Powell et al. 2005a). Not surprisingly, therefore, beer can be a major contributor to $\mathrm{Si}$ intake in the Western diet, especially for men (Pennington, 1991; Jugdaohsingh et al. 2002), contributing, on average, between 11 and $24 \%$ total daily Si intake (Jugdaohsingh et al. 2002, 2004). In contrast, levels of $\mathrm{Si}$ in wines are more varied and, although they can be as high as some beers $(7-23 \mathrm{mg} / \mathrm{l}$ in a recent small analysis; Powell et al. $2005 a$ ), actual intakes of $\mathrm{Si}$ in terms of servings are $\geq 5$ fold lower $(0.62-2.89 \mathrm{mg}$ Si per serving for wine compared with $3 \cdot 8-16 \cdot 3 \mathrm{mg} \mathrm{Si}$ per serving for beers, depending on the exact choice of beverage and serving size; Powell et al. 2005a). Moreover, the wines with the higher levels of Si may have achieved this level as part of the beverage processing, in which case chemical speciation and bioavailability of the Si is unclear (Powell et al. 2005a). Si levels in spirits are much lower (1.3 (SD 0.04) mg/l; Jugdaohsingh et al. 2004) and intakes of these beverages are totally irrelevant in terms of dietary $\mathrm{Si}$ exposure.

Si bioavailability is generally high from fluids, including beer; $\geq 55 \%$ is absorbed, much of which is then rapidly excreted by the kidneys (Bellia et al. 1994; Sripanyakorn et al. 2004). Coupled with basic chemical speciation data, this finding suggests that $\mathrm{Si}$ is present in beer as the soluble and readily-absorbable form $\mathrm{Si}(\mathrm{OH})_{4}$ (Sripanyakorn et al. 2004).

\section{Dietary silicon and bone}

Mounting evidence over the last 30 years supports a biological role for $\mathrm{Si}$ in bone and connective tissue health, and includes evidence derived from cellular, animal and human studies (for review, see Sripanyakorn et al. 2005). More recent studies have shown that dietary $\mathrm{Si}$, as soluble orthosilicic acid, which is in equilibrium with a very small amount of the orthosilicate anion $\left(\mathrm{Si}(\mathrm{OH})_{3} \mathrm{O}^{-}\right)$, has anabolic effects on bone cells (Reffitt et al. 2003) and in animal models of post-menopausal osteoporosis (Hott et al. 1993; Rico et al. 2000). In the animal studies it has been shown that supplemental Si not only inhibits bone loss but also increases femoral BMD above that of controls, suggesting that Si may have both anti-resorptive and anabolic properties (Hott et al. 1993; Rico et al. 2000). There are few studies of $\mathrm{Si}$ in human subjects, but they have also shown that supplemental $\mathrm{Si}(6-14 \mathrm{mg} / \mathrm{d})$ not only reduces bone loss but it may increase BMD by $1-5 \%$ in postmenopausal women (8-28 subjects per group) with low bone mass (Schiano et al. 1979; Eisinger \& Clairet, 1993; Spector et al. 2005). Additionally, in a recent cross-sectional study in the Framingham Offspring Cohort it has been found that dietary $\mathrm{Si}$ intake is positively associated with BMD in premenopausal women, less so in men and

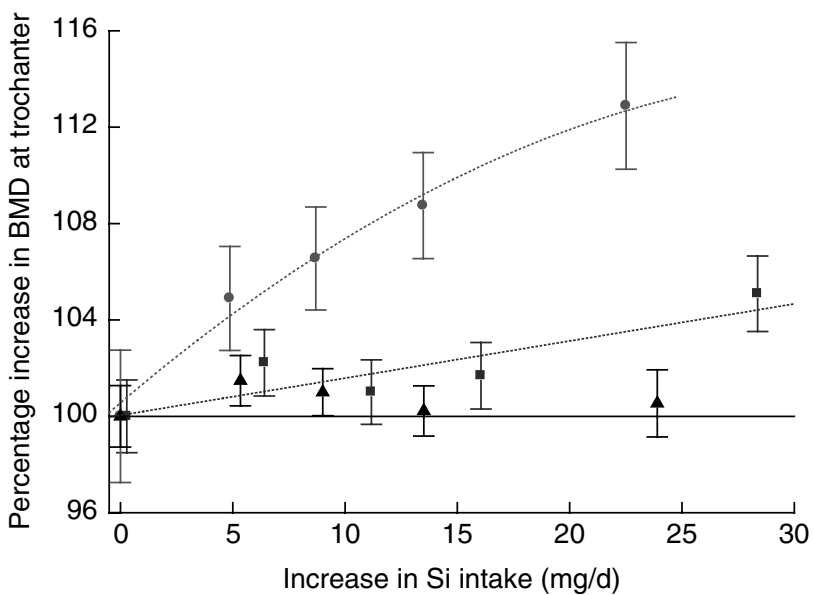

Fig. 2. Increased silicon intake is associated with increased bone mineral density (BMD) at the trochanter (site of the femur that is rich in trabecular bone) in premenopausal women $(\mathbf{O})$ and in men ( $\boldsymbol{\square})$, but not in post-menopausal women $(\boldsymbol{\Delta})$. Values are means with their standard errors represented by vertical bars for 299 premenopausal women, 1220 men and 1260 post-menopausal women participating in the Framingham Osteoporosis Study (Jugdaohsingh et al. 2004). The association was adjusted for all known potential confounding factors. Test for linearity: $P=0.004$ and $P=0.03$ for premenopausal women and for men respectively.

not at all in post-menopausal women (Jugdaohsingh et al. 2004). These results, in pre- and post-menopausal women, have recently been confirmed in a cohort of the UK population (Macdonald et al. 2005).

Altogether, $\mathrm{Si}$ does seem to play an important, if not essential, role in bone and connective tissue health and, although a number of possible mechanisms have been proposed, the exact role or biochemical function of $\mathrm{Si}$ remains enigmatic.

\section{Beer, silicon and bone}

Since beer is a major source of well-absorbed $\mathrm{Si}$, an investigation has been undertaken into whether the contribution of $\mathrm{Si}$ from beer ingestion could contribute to the positive effects of moderate alcohol consumption on bone. First, as noted earlier, one $300-574 \mathrm{ml}$ serving of beer would contribute $4-16 \mathrm{mg}$ dietary $\mathrm{Si} / \mathrm{d}$ (or $2-9 \mathrm{mg} \mathrm{Si}$ absorbed/d if bioavailability is taken into consideration), which could be enough to detect an association with BMD based on previous Si intake and BMD data (Jugdaohsingh et al. 2004). Indeed, in this previous work an increase in $\mathrm{Si}$ intake of $5-6 \mathrm{mg} \mathrm{Si} / \mathrm{d}$ was shown to be associated with a $2-5 \%$ increase in BMD at the trochanter in men and in premenopausal women (see Fig. 2). Second, also in this previous work, the association between beer intake and adjusted BMD, with and without a mathematical correction for $\mathrm{Si}$ intake, was investigated. Correcting for the Si contribution from beer was found to attenuate the positive association and reduce or negate the significance of the association between beer intake and BMD (Jugdaohsingh et al. 2004). Similar investigations on the intake of nonbeer alcohols have shown no effect of Si correction on the alcohol-BMD association, because of the small contribution of $\mathrm{Si}$ intake from non-beer alcohols (Jugdaohsingh 
et al. 2004). Thus, these findings suggest that the Si component of beer may explain or contribute to some of the positive effects of moderate alcohol consumption on bone. However, as noted previously, these findings are based on basic regression models as an initial 'global overview' and further, more detailed, studies are required using categorical data to really distinguish the role of $\mathrm{Si}$ from that of ethanol and/or other components in the association of the intakes of different alcoholic beverages with bone health.

\section{Conclusion}

Thus, in conclusion, it is becoming well established that moderate ingestion of alcoholic beverages is associated with increased BMD, a marker of bone health. However, the mechanisms are unknown. In the present review the current evidence has been summarised and potential mechanisms discussed, and a case has been made for moderate ethanol ingestion as the primary factor, through acute suppression of bone resorption. Si has also been indicated as a major constituent of beer that may additionally promote bone formation. The effects on bone health of other dietary constituents that are obtained through moderate ingestion of alcoholic beverages are probably not large, although further work is needed in human subjects. Thus, there may be differences between the three major classes of alcoholic beverages (wines, spirits and beers) in their associations with BMD as a result of differing patterns of alcohol exposure, differing $\mathrm{Si}$ intakes and, potentially, differing exposures to phytochemicals.

Further epidemiological studies incorporating measures of markers of bone turnover as well as BMD are thus required to dissect out the role of Si $v$. that of ethanol and/ or other components in alcoholic beverages and to further elucidate mechanisms underlying the relationships between moderate drinking and bone health. Ultimately, the data provided from acute metabolism studies (e.g. of ethanolinduced suppression of bone resorption) and those obtained from epidemiological studies for the effects of $\mathrm{Si}$ and/or other beverage-related phytochemicals on bone, could combine in a model that quantitatively explains the influence of moderate ingestion of alcoholic beverages on bone health in different populations. This outcome should inform the debate on alcohol and public health as well as defining and communicating moderation.

\section{Acknowledgement}

The authors would like to thank Pippa Eyre for secretarial help in preparing the manuscript and Dr Gail Goldberg for expert help in refining and editing the manuscript. We are also grateful to Drs Henk Hendriks and Norbert Frank for their expert reviews.

\section{References}

Agarwal S, Long P, Seyedain A, Piesco N, Shree A \& Gassner R (2003) A central role for the nuclear factor-kappaB pathway in anti-inflammatory and proinflammatory actions of mechanical strain. FASEB Journal 17, 899-901.
Albrand G, Munoz F, Sornay-Rendu E, DuBoeuf F \& Delmas PD (2003) Independent predictors of all osteoporosis-related fractures in healthy postmenopausal women: the OFELY study. Bone 32, 78-85.

Andrade PB, Oliveira BM, Seabra RM, Ferreira MA, Ferreres F \& Garcia-Viguera C (2001) Analysis of phenolic compounds in Spanish Albrarino and Portuguese Alvarinho and Loureiro wines by capillary zone electrophoresis and high-performance liquid chromatography. Electrophoresis 22, 1568-1572.

Andreou V, D'Addario M, Zohar R, Sukhu B, Casper RF, Ellen RP \& Tenenbaum HC (2004) Inhibition of osteogenesis in vitro by a cigarette smoke-associated hydrocarbon combined with Porphyromonas gingivalis lipopolysaccharide: reversal by resveratrol. Journal of Periodontology 75, 939-948.

Bainbridge KE, Sowers M, Lin X \& Harlow SD (2004) Risk factors for low bone mineral density and the 6-year rate of bone loss among premenopausal and perimenopausal women. Osteoporosis International 15, 439-446.

Banse X, Devogelaer JP, Lafosse A, Sims TJ, Grynpas M \& Bailey AJ (2002) Cross-link profile of bone collagen correlates with structural organization of trabeculae. Bone 31, 70-76.

Baron JA, Farahmand BY, Weiderpass E, Michaelsson K, Alberts A, Persson I \& Ljunghall S (2001) Cigarette smoking, alcohol consumption, and risk of hip fracture in women. Archives of Internal Medicine 161, 983-988.

Bauer DC, Browner WS, Cauley JA, Orwoll ES, Scott JC, Black DM, Tao JL \& Cummings SR (1993) Factors associated with appendicular bone mass in older women. The Study of Osteoporotic Fractures Research Group. Annals of Internal Medicine 118, 657-665.

Beck GR Jr, Moran E \& Knecht N (2003) Inorganic phosphate regulates multiple genes during osteoblast differentiation, including Nrf2. Experimental Cell Research 288, 288-300.

Beck GR Jr, Zerler B \& Moran E (2001) Gene array analysis of osteoblast differentiation. Cell Growth and Differentiation 12, 61-83.

Bellia JP, Birchall JD \& Roberts NB (1994) Beer: a dietary source of silicon. Lancet 343, 235.

Bessho M (2003) Prediction of the strength and fracture location of the femoral neck by means of the CT based finite element method: a preliminary study on the patients with hip fracture. Bone 32, S80.

Borah B, Dufresne TE, Chmielewski PA, Manhart MD \& Watts NB (2003) Risedronate preserves trabecular architecture in early post-menopausal women in just 1 year; a paired biopsy study using 3-dimentional microcomputed tomography. Bone 32, S78.

Bowers JL, Tyulmenkov VV, Jernigan SC \& Klinge CM (2000) Resveratrol acts as a mixed agonist/antagonist for estrogen receptors alpha and beta. Endocrinology 141, 3657-3667.

Boyan BD, Lohmann CH, Sisk M, Liu Y, Sylvia VL, Cochran DL, Dean DD \& Schwartz Z (2001) Both cyclooxygenase-1 and cyclooxygenase-2 mediate osteoblast response to titanium surface roughness. Journal of Biomedical Materials Research 55, 350-359.

Boyce BF, Li P, Yao Z, Zhang Q, Badell IR, Schwarz EM, O'Keefe RJ \& Xing L (2005) TNF-alpha and pathologic bone resorption. The Keio Journal of Medicine 54, 127-131.

Burns J, Gardner PT, Matthews D, Duthie GG, Lean ME \& Crozier A (2001) Extraction of phenolics and changes in antioxidant activity of red wines during vinification. Journal of Agricultural and Food Chemistry 49, 5797-5808.

Burr DB (2002) The contribution of the organic matrix to bone's material properties. Bone 31, 8-11.

Carando S, Teissedre PL, Pascual-Martinez L \& Cabanis JC (1999) Levels of flavan-3-ols in French wines. Journal of Agricultural and Food Chemistry 47, 4161-4166. 
Cefalu CA (2004) Is bone mineral density predictive of fracture risk reduction? Current Medical Research and Opinion 20, 341-349.

Chae HJ, Chae SW, Reed JC \& Kim HR (2004) Salicylate regulates COX-2 expression through ERK and subsequent NF-kappaB activation in osteoblasts. Immunopharmacology and Immunotoxicology 26, 75-91.

Chen CY, Jang JH, Li MH \& Surh YJ (2005) Resveratrol upregulates heme oxygenase-1 expression via activation of NF-E2related factor 2 in PC12 cells. Biochemical and Biophysical Research 331, 993-1000.

Chen XL, Dodd G, Thomas S, Zhang X, Wasserman MA, Rovin BH \& Kunsch C (2006) Activation of the Nrf2/ARE pathway protects endothelial cells from oxidant injury and inhibits inflammatory gene expression. American Journal of Physiology (In the Press).

Chen XL \& Kunsch C (2004) Induction of cytoprotective genes through Nrf2/antioxidant response element pathway: a new therapeutic approach for the treatment of inflammatory diseases. Current Pharmaceutical Design 10, 879-891.

Choi EM \& Hwang JK (2003) Effects of (+)-catechin on the function of osteoblastic cells. Biological and Pharmaceutical Bulletin 26, 523-526.

Colantoni A, Emanuele MA, Kovacs EJ, Villa E \& Van Thiel DH (2002) Hepatic estrogen receptors and alcohol intake. Molecular and Cellular Endocrinology 193, 101-104.

Coutelle C, Hohn B, Benesova M, Oneta CM, Quattrochi P, Roth HJ, Schmidt-Gayk H, Schneeweiss A, Bastert G \& Seitz HK (2004) Risk factors in alcohol associated breast cancer: alcohol dehydrogenase polymorphism and estrogens. International Journal of Oncology 25, 1127-1132.

Cumming RG \& Klineberg RJ (1994) Case-control study of risk factors for hip fractures in the elderly. American Journal of Epidemiology 139, 493-503.

Cummings SR, Bates D \& Black DM (2005) Clinical use of bone densitometry: scientific review. Journal of the American Medical Association 288, 1889-1897.

da Luz PL \& Coimbra SR (2004) Wine, alcohol and atherosclerosis: clinical evidences and mechanisms. Brazilian Journal of Medical and Biological Research 37, 1275-1295.

Dawson DA (2003) Methodological issues in measuring alcohol use. Alcohol Research and Health 27, 18-29.

de Lorimier AA (2000) Alcohol, wine, and health. American Journal of Surgery 180, 357-361.

Delaisse JM, Eeckhout Y \& Vaes G (1986) Inhibition of bone resorption in culture by (+)-catechin. Biochemical Pharmacology 35, 3091-3094.

Diez F (2002) Guidelines for the diagnosis of osteoporosis by densitometric methods. Journal of Manipulative and Physiological Therapeutics 25, 403-415.

Dugo G, Salvo F, Dugo P, La Torre GL \& Mondello L (2003) Antioxidants in Sicilian wines: analytic and compositive aspects. Drugs under Experimental and Clinical Research 29, 189-202.

Eastell R, Barton I, Hannon RA, Chines A, Garnero P \& Delmas PD (2003) Relationship of early changes in bone resorption to the reduction in fracture risk with risedronate. Journal of Bone and Mineral Research 18, 1051-1056.

Ebeling PR \& Akesson K (2001) Role of biochemical markers in the management of osteoporosis. Best Practice and Research Clinical Rheumatology 15, 385-400.

Effenberger KE, Johnsen SA, Monroe DG, Spelsberg TC \& Westendorf JJ (2005) Regulation of osteoblastic phenotype and gene expression by hop-derived phytoestrogens. Journal of Steroid Biochemistry and Molecular Biology 96, 387-399.

Eisinger J \& Clairet D (1993) Effects of silicon, fluoride, etidronate and magnesium on bone mineral density: A retrospective study. Magnesium Research 6, 247-249.
Elliott ME \& Binkley N (2004) Evaluation and measurement of bone mass. Epilepsy and Behaviour 5, Suppl. 2, S16-S23.

Epstein E (1999) Silicon. Annual review of plant physiology and plant molecular biology. Annual Reviews 50, 641-664.

Estrov Z, Shishodia S, Faderl S, Harris D, Van Q, Kantarjian HM, Talpaz M \& Aggarwal BB (2003) Resveratrol blocks interleukin-1beta-induced activation of the nuclear transcription factor NF-kappaB, inhibits proliferation, causes S-phase arrest, and induces apoptosis of acute myeloid leukemia cells. Blood 102, 987-995.

Fan S, Meng Q, Gao B, Grossman J, Yadegari M, Goldberg ID \& Rosen EM (2000) Alcohol stimulates estrogen receptor signaling in human breast cancer cell lines. Cancer Research $\mathbf{6 0}$, $5635-5639$.

Fehily AM, Coles RJ, Evans WD \& Elwood PC (1992) Factors affecting bone density in young adults. American Journal of Clinical Nutrition 56, 579-586.

Felsenberg D \& Boonen S (2005) The bone quality framework: determinants of bone strength and their interrelationships, and implications for osteoporosis management. Clinical Therapeutics 27, 1-11.

Felson DT, Zhang Y, Hannan MT, Kannel WB \& Kiel DP (1995) Alcohol intake and bone mineral density in elderly men and women. The Framingham Study. American Journal of Epidemiology 142, 485-492.

Feskanich D, Korrick SA, Greenspan SL, Rosen HN \& Colditz GA (1999) Moderate alcohol consumption and bone density among postmenopausal women. Journal of Women's Health $\mathbf{8}$, $65-73$.

Fukunaga M (2003) Assessing bone density. Bone 32, S70-S71.

Ganry O, Baudoin C \& Fardellone P (2000) Effect of alcohol intake on bone mineral density in elderly women: The EPIDOS Study. Epidemiologie de l'Osteoporose. American Journal of Epidemiology 151, 773-780.

Garcia-Sanchez A, Gonzalez-Calvin JL, Diez-Ruiz A, Casals JL, Gallego-Rojo F \& Salvatierra D (1995) Effect of acute alcohol ingestion on mineral metabolism and osteoblastic function. Alcohol and Alcoholism 30, 449-453.

Garnero P \& Delmas PD (2004) Contribution of bone mineral density and bone turnover markers to the estimation of risk of osteoporotic fracture in postmenopausal women. Journal of Musculoskeletal and Neuronal Interactions 4, 50-63.

Garnero P, Ferreras M, Karsdal MA, Nicamhlaoibh R, Risteli J, Borel O, Qvist P, Delmas PD, Foged NT \& Delaisse JM (2003a) The type I collagen fragments ICTP and CTX reveal distinct enzymatic pathways of bone collagen degradation. Journal of Bone and Mineral Research 18, 859-867.

Garnero P, Mulleman D, Munoz F, Sornay-Rendu E \& Delmas PD (2003b) Long-term variability of markers of bone turnover in postmenopausal women and implications for their clinical use: the OFELY study. Journal of Bone and Mineral Research 18, 1789-1794.

Gavaler JS \& Love K (1992) Detection of the relationship between moderate alcoholic beverage consumption and serum levels of estradiol in normal postmenopausal women: effects of alcohol consumption quantitation methods and sample size adequacy. Journal of Studies on Alcohol 53, 389-394.

Gavaler JS, Love K, Van Thiel D, Farholt S, Gluud C, Monteiro E, Galvao-Teles A, Ortega TC \& Cuervas-Mons V (1991) An international study of the relationship between alcohol consumption and postmenopausal estradiol levels. Alcohol and Alcoholism 1, Suppl., 327-330.

Gerdhem P, Ivaska KK, Alatalo SL, Halleen JM, Hellman J, Isaksson A, Pettersson K, Vaananen HK, Akesson K \& Obrant KJ (2004) Biochemical markers of bone metabolism and prediction of fracture in elderly women. Journal of Bone and Mineral Research 19, 386-393. 
Gerhauser C \& Frank N (2005) Xanthohumol, a new all-rounder? Molecular Nutrition and Food Research 49, 821-823.

Ginsburg ES (1999) Estrogen, alcohol and breast cancer risk. Journal of Steroid Biochemistry and Molecular Biology 69, 299-306.

Ginsburg ES, Mello NK, Mendelson JH, Barbieri RL, Teoh SK, Rothman M, Gao X \& Sholar JW (1996) Effects of alcohol ingestion on estrogens in postmenopausal women. Journal of the American Medical Association 276, 1747-1751.

Goldberg DM, Yan J \& Soleas GJ (2003) Absorption of three wine-related polyphenols in three different matrices by healthy subjects. Clinical Biochemistry 36, 79-87.

Goodin MG, Fertuck KC, Zacharewski TR \& Rosengren RJ (2002) Estrogen receptor-mediated actions of polyphenolic catechins in vivo and in vitro. Toxicological Sciences 69, 354-361.

Graafmans WC, Lips P, Ooms ME, van Leeuwen JP, Pols HA \& Uitterlinden AG (1997) The effect of vitamin D supplementation on the bone mineral density of the femoral neck is associated with vitamin D receptor genotype. Journal of Bone and Mineral Research 12, 1241-1245.

Grainge MJ, Coupland CA, Cliffe SJ, Chilvers CE \& Hosking DJ (1998) Cigarette smoking, alcohol and caffeine consumption, and bone mineral density in postmenopausal women. The Nottingham EPIC Study Group. Osteoporosis International 8, 355-363.

Guillemant J, Le HT, Accarie C, du Montcel ST, Delabroise AM, Arnaud MJ \& Guillemant S (2000) Mineral water as a source of dietary calcium: acute effects on parathyroid function and bone resorption in young men. American Journal of Clinical Nutrition 71, 999-1002.

Guillemant JA, Accarie CM, de la Gueronniere V \& Guillemant SE (2003) Different acute responses of serum type I collagen telopeptides, CTX, NTX and ICTP, after repeated ingestion of calcium. Clinica Chimica Acta 337, 35-41.

Ha H, Kwak HB, Lee SW, Jin HM, Kim HM, Kim HH \& Lee ZH (2004) Reactive oxygen species mediate RANK signaling in osteoclasts. Experimental Cell Research 301, 119-127.

Hankinson SE, Willett WC, Manson JE, Hunter DJ, Colditz GA, Stampfer MJ, Longcope C \& Speizer FE (1995) Alcohol, height, and adiposity in relation to estrogen and prolactin levels in postmenopausal women. Journal of the National Cancer Institute 87, 1297-1302.

Hoidrup S, Gronbaek M, Gottschau A, Lauritzen JB \& Schroll M (1999) Alcohol intake, beverage preference, and risk of hip fracture in men and women. Copenhagen Centre for Prospective Population Studies. American Journal of Epidemiology 149, 993-1001.

Holbrook TL \& Barrett-Connor E (1993) A prospective study of alcohol consumption and bone mineral density. British Medical Journal 306, 1506-1509.

Horcajada-Molteni MN, Crespy V, Coxam V, Davicco MJ, Remesy C \& Barlet JP (2000) Rutin inhibits ovariectomyinduced osteopenia in rats. Journal of Bone and Mineral Research 15, 2251-2258.

Hott M, de Pollak C, Modrowski D \& Marie PJ (1993) Short term effects of organic silicon on trabecular bone structure in mature ovariectimised rats. Calcified Tissue International 53, $174-179$.

Huang Z, Himes JH \& McGovern PG (1996) Nutrition and subsequent hip fracture risk among a national cohort of white women. American Journal of Epidemiology 144, 124-134.

Huopio J, Kroger H, Honkanen R, Saarikoski S \& Alhava E (2000) Risk factors for perimenopausal fractures: a prospective study. Osteoporosis International 11, 219-227.

Ilich JZ, Brownbill RA, Tamborini L \& Crncevic-Orlic Z (2002) To drink or not to drink: how are alcohol, caffeine and past smoking related to bone mineral density in elderly women? Journal of the American College of Nutrition 21, 536-544.

International Center for Alcohol Policies (2003) International Drinking Guidelines. International Center for Alcohol Policies Reports, issue 14. Washington, DC: ICAP.

Ioannidis JP, Stavrou I, Trikalinos TA, Zois C, Brandi ML, Gennari L, Albagha O, Ralston SH \& Tsatsoulis A (2002) Association of polymorphisms of the estrogen receptor alpha gene with bone mineral density and fracture risk in women: a meta-analysis. Journal of Bone and Mineral Research 17, 2048-2060.

Johnell O, Kanis JA, Oden A, Johansson H, De Laet C, Delmas P et al. (2005) Predictive value of BMD for hip and other fractures. Journal of Bone and Mineral Research 20, 1185-1194.

Jugdaohsingh R, Anderson SHC, Tucker KL, Elliott H, Kiel DP, Thompson RPH \& Powell JJ (2002) Dietary silicon intake and absorption. American Journal of Clinical Nutrition $\mathbf{7 5}$, 887-893.

Jugdaohsingh R, Tucker KL, Qiao N, Cupples LA, Kiel DP \& Powell JJ (2004) Dietary silicon intake is positively associated with bone mineral density in men and premenopausal women of the Framingham Offspring cohort. Journal of Bone and Mineral Research 19, 297-307.

Kamel S, Fardellone P, Meddah B, Lorget-Gondelmann F, Sebert JL \& Brazier M (1998) Response of several markers of bone collagen degradation to calcium supplementation in postmenopausal women with low calcium intake. Clinical Chemistry 44, 1437-1442.

Kanis JA, Johansson H, Johnell O, Oden A, De Laet C, Eisman JA, Pols H \& Tenenhouse A (2005) Alcohol intake as a risk factor for fracture. Osteoporosis International 16, 737-742.

Katsouyanni K, Boyle P \& Trichopoulos D (1991) Diet and urine estrogens among postmenopausal women. Oncology 48, 490-494.

Khosla S (2003) Surrogates for fracture endpoints in clinical trials. Journal of Bone and Mineral Research 18, 1146-1149.

Klatsky AL (2003) Drink to your health? Scientific American 288, 74-81.

Kleerekoper M \& Nelson DA (1997) Which bone density measurement? Journal of Bone and Mineral Research 12, 712-714.

Klinge CM, Risinger KE, Watts MB, Beck V, Eder R \& Jungbauer A (2003) Estrogenic activity in white and red wine extracts. Journal of Agricultural and Food Chemistry 51, $1850-1857$.

Kroger H, Tuppurainen M, Honkanen R, Alhava E \& Saarikoski $\mathrm{S}$ (1994) Bone mineral density and risk factors for osteoporosis - a population-based study of 1600 perimenopausal women. Calcified Tissue International 55, 1-7.

Laitinen K, Tahtela R \& Valimaki M (1992) The dose-dependency of alcohol-induced hypoparathyroidism, hypercalciuria, and hypermagnesuria. Bone and Mineral 19, 75-83.

Laitinen K, Valimaki M \& Keto P (1991) Bone mineral density measured by dual-energy X-ray absorptiometry in healthy Finnish women. Calcified Tissue International 48, 224-231.

Liu ZP, Li WX, Yu B, Huang J, Sun J, Huo JS \& Liu CX (2005) Effects of trans-resveratrol from Polygonum cuspidatum on bone loss using the ovariectomized rat model. Journal of Medicinal Food 8, 14-19.

Longnecker MP (1993) Do hormones link alcohol with breast cancer? Journal of the National Cancer Institute 85, 692-693.

Lugasi A \& Hovari J (2003) Antioxidant properties of commercial alcoholic and nonalcoholic beverages. Die Nahrung 47, 79-86.

McGartland CP, Robson PJ, Murray LJ, Cran GW, Savage MJ, Watkins DC, Rooney MM \& Boreham CA (2004) Fruit and vegetable consumption and bone mineral density: the Northern 
Ireland Young Hearts Project. American Journal of Clinical Nutrition 80, 1019-1023.

Macdonald HM, Hardcastle AE, Jugdaohsingh R, Reid DM \& Powell JJ (2005) Dietary silicon intake is associated with bone mineral density in premenopausal women and postmenopausal women taking HRT. Journal of Bone and Mineral Research 20, S393.

Macdonald HM, New SA, Golden MH, Campbell MK \& Reid DM (2004) Nutritional associations with bone loss during the menopausal transition: evidence of a beneficial effect of calcium, alcohol, and fruit and vegetable nutrients and of a detrimental effect of fatty acids. American Journal of Clinical Nutrition 79, 155-165.

Madhan B, Subramanian V, Rao JR, Nair BU \& Ramasami T (2005) Stabilization of collagen using plant polyphenol: role of catechin. International Journal of Biological Macromolecules 37, 47-53.

Malavolta N, Mule R \& Frigato M (2004) Quantitative ultrasound assessment of bone. Aging Clinical and Experimental Research 16, Suppl., 23-28.

Manach C, Williamson G, Morand C, Scalbert A \& Remesy C (2005) Bioavailability and bioefficacy of polyphenols in humans. I. Review of 97 bioavailability studies. American Journal of Clinical Nutrition 81, 230S-242S.

Manolagas SC, Kousteni S \& Jilka RL (2002) Sex steroids and bone. Recent Progress in Hormone Research 57, 385-409.

Marie PJ \& Hott M (1986) Short-term effects of fluoride and strontium on bone formation and resorption in the mouse. Metabolism: Clinical and Experimental 35, 574-551.

Martin CA, Mainous AG 3rd, Curry T \& Martin D (1999) Alcohol use in adolescent females: correlates with estradiol and testosterone. American Journal on Addictions 8, 9-14.

Marx J (2004) Coming to grips with bone loss. Science 305, $1420-1422$.

May H, Murphy S \& Khaw KT (1995) Alcohol consumption and bone mineral density in older men. Gerontology 41, 152-158.

Melton LJ 3rd, Crowson CS, O'Fallon WM, Wahner HW \& Riggs BL (2003) Relative contributions of bone density, bone turnover, and clinical risk factors to long-term fracture prediction. Journal of Bone and Mineral Research 18, 312-318.

Miller PD, Hochberg MC, Wehren LE, Ross PD \& Wasnich RD (2005) How useful are measures of BMD and bone turnover? Current Medical Research and Opinion 21, 545-554.

Miyamoto M, Matsushita Y, Kiyokawa A, Fukuda C, Iijima Y, Sugano M \& Akiyama T (1998) Prenylflavonoids: a new class of non-steroidal phytoestrogen (Part 2). Estrogenic effects of 8 -isopentenylnaringenin on bone metabolism. Planta Medica 64, 516-519.

Mizutani K, Ikeda K, Kawai Y \& Yamori Y (1998) Resveratrol stimulates the proliferation and differentiation of osteoblastic MC3T3-E1 cells. Biochemical and Biophysical Research Comunications 253, 859-863.

Mizutani K, Ikeda K, Kawai Y \& Yamori Y (2000) Resveratrol attenuates ovariectomy-induced hypertension and bone loss in stroke-prone spontaneously hypertensive rats. Journal of Nutritional Science and Vitaminology 46, 78-83.

Muhlbauer RC \& Fleisch H (1990) A method for continual monitoring of bone resorption in rats: evidence for a diurnal rhythm. American Journal of Physiology 259, R679-R689.

Muhlbauer RC, Lozano A, Reinli A \& Wetli H (2003) Various selected vegetables, fruits, mushrooms and red wine residue inhibit bone resorption in rats. Journal of Nutrition 133 3592-3597.

Muti P, Trevisan M, Micheli A, Krogh V, Bolelli G, Sciajno R, Schunemann HJ \& Berrino F (1998) Alcohol consumption and total estradiol in premenopausal women. Cancer Epidemiology, Biomarkers \& Prevention 7, 189-193.
Nakagawa H, Wachi M, Woo JT, Kato M, Kasai S, Takahashi F, Lee IS \& Nagai K (2002) Fenton reaction is primarily involved in a mechanism of (-)-epigallocatechin-3-gallate to induce osteoclastic cell death. Biochemical and Biophysical Research Comunications 292, 94-101.

Nardini M, Natella F, Scaccini C \& Ghiselli A (2006) Phenolic acids from beer are absorbed and extensively metabolized in humans. Journal of Nutritional Biochemistry 17, 14-22.

New SA, Bolton-Smith C, Grubb DA \& Reid DM (1997) Nutritional influences on bone mineral density: a cross-sectional study in premenopausal women. American Journal of Clinical Nutrition 65, 1831-1839.

Nguyen TV, Eisman JA, Kelly PJ \& Sambrook PN (1996) Risk factors for osteoporotic fractures in elderly men. American Journal of Epidemiology 144, 255-263.

Nookandeh A, Frank N, Steiner F, Ellinger R, Schneider B, Gerhauser C \& Becker H (2004) Xanthohumol metabolites in faeces of rats. Phytochemistry 65, 561-570.

Park YH, Han DW, Suh H, Ryu GH, Hyon SH, Cho BK \& Park JC (2003) Protective effects of green tea polyphenol against reactive oxygen species-induced oxidative stress in cultured rat calvarial osteoblast. Cell Biology and Toxicology 19, 325-337.

Paschalis EP, Shane E, Lyritis G, Skarantavos G, Mendelsohn R \& Boskey AL (2004) Bone fragility and collagen cross-links. Journal of Bone and Mineral Research 19, 2000-2004.

Pennington JAT (1991) Silicon in food and diets. Food Additives and Contaminants 8, 97-118.

Powell JJ, McNaughton SA, Jugdaohsingh R, Anderson S, Dear J, Khot $\mathrm{F}$ et al. (2005a) A provisional database for the silicon content of foods in the United Kingdom. British Journal of Nutrition 94, 804-812.

Powell JJ, Sripanyakorn S \& Jugdaohsingh R (2005b) Moderate ingestion of alcohol is associated with acute ethanol-induced suppression of circulating CTx in a PTH-independent fashion. Osteoporosis International 16, Suppl. 4, S31.

Prentice A, Parsons TJ \& Cole TJ (1994) Uncritical use of bone mineral density in absorptiometry may lead to size-related artifacts in the identification of bone mineral determinants. American Journal of Clinical Nutrition 60, 837-842.

Promberger A, Dornstauder E, Fruhwirth C, Schmid ER \& Jungbauer A (2001) Determination of estrogenic activity in beer by biological and chemical means. Journal of Agricultural and Food Chemistry 49, 633-640.

Prouillet C, Maziere JC, Maziere C, Wattel A, Brazier M \& Kamel S (2004) Stimulatory effect of naturally occurring flavonols quercetin and kaempferol on alkaline phosphatase activity in MG-63 human osteoblasts through ERK and estrogen receptor pathway. Biochemical Pharmacology 67, 1307-1313.

Prynne C, Mishra GD, O'Connell M, Muniz-Terrera G, Laskey MA, Yan L, Prentice A \& Ginty F (2006) Fruit and vegetable consumption and bone mineral status: a cross sectional study across five age/gender cohorts. American Journal of Clinical Nutrition 83, 1419-1427.

Purohit V (1998) Moderate alcohol consumption and estrogen levels in postmenopausal women: a review. Alcoholism, Clinical and Experimental Research 22, 994-997.

Purohit V (2000) Can alcohol promote aromatization of androgens to estrogens? A review. Alcohol 22, 123-127.

Rapuri PB, Gallagher JC, Balhorn KE \& Ryschon KL (2000) Alcohol intake and bone metabolism in elderly women. American Journal of Clinical Nutrition 72, 1206-1213.

Rapuri PB, Kinyamu HK, Gallagher JC \& Haynatzka V (2002) Seasonal changes in calciotropic hormones, bone markers, and bone mineral density in elderly women. Journal of Clinical Endocrinology and Metabolism 87, 2024-2032. 
Rassi CM, Lieberherr M, Chaumaz G, Pointillart A \& Cournot G (2005) Modulation of osteoclastogenesis in porcine bone marrow cultures by quercetin and rutin. Cell and Tissue Research 319, 383-393.

Reffitt DM, Ogston N, Jugdaohsingh R, Cheung HJF, Evans BAJ, Thompson RPH, Powell JJ \& Hampson GN (2003) Orthosilicic acid stimulates collagen type 1 synthesis and osteoblastic differentiation in human osteoblast-like cells in vitro. Bone 32, 127-135.

Reid DM \& New SA (1997) Nutritional influences on bone mass. Proceedings of the Nutrition Society 56, 977-987.

Rico H (1990) Alcohol and bone disease. Alcohol and Alcoholism 25, 345-352.

Rico H, Gallego-Lago JL, Hernandez ER, Villa LF, SanchezAtrio A, Seco C \& Gervas JJ (2000) Effect of silicon supplement on osteopenia induced by ovariectomy in rats. Calcified Tissue International 66, 53-55.

Robbins JA, Schott AM, Garnero P, Delmas PD, Hans D \& Meunier PJ (2005) Risk factors for hip fracture in women with high BMD: EPIDOS study. Osteoporosis International 16, 149-154.

Robins SP \& New SA (1997) Markers of bone turnover in relation to bone health. Proceedings of the Nutrition Society 56, 903-914.

Roux C, Garnero P, Thomas T, Sabatier JP, Orcel P \& Audran M (2005) Recommendations for monitoring antiresorptive therapies in postmenopausal osteoporosis. Joint, Bone, Spine: Revue du Rhumatisme 72, 26-31.

Ruefer CE, Gerhauser C, Frank N, Becker H \& Kulling SE (2005) In vitro phase II metabolism of xanthohumol by human UDP-glucuronosyltransferases and sulfotransferases. Molecular Nutrition and Food Research 49, 851-856.

Saltman PD \& Strause LG (1993) The role of trace minerals in osteoporosis. Journal of the American College of Nutrition 12, 384-389.

Sangster AG, Hodson MJ \& Tubb MJ (1986) Silica in higher plants. In Silicon Biochemistry. Ciba Foundation Symposium no. 121, pp. 90-111 [RJP Williams, editor]. Chichester, West Sussex: John Wiley and Sons.

Sarkar S, Reginster JY, Crans GG, Diez-Perez A, Pinette KV \& Delmas PD (2004) Relationship between changes in biochemical markers of bone turnover and BMD to predict vertebral fracture risk. Journal of Bone and Mineral Research 19, 394-401.

Sarkola T, Makisalo H, Fukunaga T \& Eriksson CJ (1999) Acute effect of alcohol on estradiol, estrone, progesterone, prolactin, cortisol, and luteinizing hormone in premenopausal women. Alcoholism, Clinical and Experimental Research 23, 976-982.

Sato M, Kulkarni PM, Jerome C, Brommage R \& Turner C (2003) Bone mineral density under-represents the skeletal efficacy of teripretide [recombinant human parathyroid hormone (1-34)] in ovariectomized monkeys. Bone 32, S77.

Schiano A, Eisinger F, Detolle P, Laponche AM, Brisou B \& Eisinger J (1979) Silicium, tissu osseux et immunite (Silicon, bone tissue and immunity). Revue du Rhumatisme et des Maladies Osteoarticulaires 46, 483-486.

Shaw CK (1993) An epidemiologic study of osteoporosis in Taiwan. Annals of Epidemiology 3, 264-271.

Shearman AM, Karasik D, Gruenthal KM, Demissie S, Cupples LA, Housman DE \& Kiel DP (2004) Estrogen receptor beta polymorphisms are associated with bone mass in women and men: the Framingham Study. Journal of Bone and Mineral Research 19, 773-781.

Sierksma A, Sarkola T, Eriksson CJ, van der Gaag MS, Grobbee DE \& Hendriks HF (2004) Effect of moderate alcohol consumption on plasma dehydroepiandrosterone sulfate, testosterone, and estradiol levels in middle-aged men and postmenopausal women: a diet-controlled intervention study. Alcoholism, Clinical and Experimental Research 28, 780-785.

Singh SU, Casper RF, Fritz PC, Sukhu B, Ganss B, Girard B Jr, Savouret JF \& Tenenbaum HC (2000) Inhibition of dioxin effects on bone formation in vitro by a newly described aryl hydrocarbon receptor antagonist, resveratrol. Journal of Endocrinology 167, 183-195.

Singletary KW, Frey RS \& Yan W (2001) Effect of ethanol on proliferation and estrogen receptor-alpha expression in human breast cancer cells. Cancer Letters 165, 131-137.

Smeets-Goevaers CG, Lesusink GL, Papapoulos SE, Maartens LW, Keyzer JJ, Weerdenburg JP, Beijers LM, Zwinderman AH, Knottnerus JA, Pols HA \& Pop VJ (1998) The prevalence of low bone mineral density in Dutch perimenopausal women: the Eindhoven perimenopausal osteoporosis study. Osteoporosis International 8, 404-409.

Soares MP, Seldon MP, Gregoire IP, Vassilevskaia T, Berberat PO, Yu J, Tsui TY \& Bach FH (2005) Heme oxygenase-1 modulates the expression of adhesion molecules associated with endothelial cell activation. Journal of Immunology 172, 3553-3563.

Spector TD, Calomme MR, Anderson S, Swaminathan R Jugdaohsingh R, Vanden Berghe DA \& Powell JJ (2005) Effect of bone turnover and BMD of low dose oral silicon as an adjunct to calcium/vitamin D3 in a randomized placebocontrolled trial. Journal of Bone and Mineral Research 20, S172.

Sripanyakorn S, Jugdaohsingh R, Elliott H, Walker C, Mehta P, Shouker S, Thompson RPH \& Powell JJ (2004) The silicon content of beer and its bioavailability in healthy volunteers. British Journal of Nutrition 91, 403-409.

Sripanyakorn S, Jugdaohsingh R, Thompson RPH \& Powell JJ (2005) Dietary silicon and bone health. British Nutrition Foundation Nutrition Bulletin 30, 222-230.

Srivastava AK, Vliet EL, Lewiecki EM, Maricic M, Abdelmalek A, Gluck O \& Baylink DJ (2005) Clinical use of serum and urine bone markers in the management of osteoporosis. Current Medical Research and Opinion 21, 1015-1026.

Stevens JF \& Page JE (2004) Xanthohumol and related prenylflavonoids from hops and beer: to your good health! Phytochemistry 65, 1317-1330.

Stevens JF, Taylor AW, Clawson JE \& Deinzer ML (1999) Fate of xanthohumol and related prenylflavonoids from hops to beer. Journal of Agricultural and Food Chemistry 47, 2421-2428.

Stoss H, Pesch HJ \& Spranger J (1979) Therapie der Osteogenesis imperfecta mit (+)-Catechin. Elektronenmikroskopische und klinische Befunde (Treatment of osteogenesis imperfecta with (+)-catechin. Electromicroscopic and clinical findings). Deutsche Medizinische Wochenschrift 104, 1774, 1777-1778.

Suganuma M, Okabe S, Oniyama M, Tada Y, Ito H \& Fujiki H (1998) Wide distribution of [3H](-)-epigallocatechin gallate, a cancer preventive tea polyphenol, in mouse tissue. Carcinogenesis 19, 1771-1776.

Tedesco I, Nappo A, Petitto F, Iacomino G, Nazzaro F, Palumbo R \& Russo GL (2005) Antioxidant and cytotoxic properties of lyophilized beer extracts on HL-60 cell line. Nutrition and Cancer 52, 74-83.

Teegarden D, Lyle RM, Proulx WR, Johnston CC \& Weaver CM (1999) Previous milk consumption is associated with greater bone density in young women. American Journal of Clinical Nutrition 69, 1014-1017.

Teti A (2005) New concepts in osteoclast pathophysiology. BoneKEy-Osteovision 6, 17-22.

Tobe H, Muraki Y, Kitamura K, Komiyama O, Sato Y, Sugioka T, Maruyama HB, Matsuda E \& Nagai M (1997) Bone resorption inhibitors from hop extract. Bioscience, Biotechnology, and Biochemistry 61, 158-159. 
Tsang C, Higgins S, Duthie GG, Duthie SJ, Howie M, Mullen W, Lean ME \& Crozier A (2005) The influence of moderate red wine consumption on antioxidant status and indices of oxidative stress associated with CHD in healthy volunteers. British Journal of Nutrition 93, 233-240.

Tucker KL, Hannan MT, Chen H, Cupples LA, Wilson PW \& Kiel DP (1999) Potassium, magnesium, and fruit and vegetable intakes are associated with greater bone mineral density in elderly men and women. American Journal of Clinical Nutrition 69, 727-736.

Tudor-Locke C \& McColl RS (2000) Factors related to variation in premenopausal bone mineral status: a health promotion approach. Osteoporosis International 11, 1-24.

Turner RT, Evans GL, Zhang M, Maran A \& Sibonga JD (1999) Is resveratrol an estrogen agonist in growing rats? Endocrinology 140, 50-54.

Turner RT, Kidder LS, Kennedy A, Evans GL \& Sibonga JD (2001) Moderate alcohol consumption suppresses bone turnover in adult female rats. Journal of Bone and Mineral Research 16, 589-594.

Varo P \& Koivistoinen P (1980) Mineral element composition of Finish foods: XII. General discussion and nutritional evaluation. Acta Agriculturae Scandinavica 22, Suppl., 166-171.

Walle T, Hsieh F, DeLegge MH, Oatis JE Jr \& Walle UK (2004) High absorption but very low bioavailability of oral resveratrol in humans. Drug Metabolism and Disposition 32, 1377-1382.

Wattel A, Kamel S, Mentaverri R, Lorget F, Prouillet C, Petit JP, Fardelonne P \& Brazier M (2003) Potent inhibitory effect of naturally occurring flavonoids quercetin and kaempferol on in vitro osteoclastic bone resorption. Biochemical Pharmacology 65, 35-42.

Wattel A, Kamel S, Prouillet C, Petit JP, Lorget F, Offord E \& Brazier M (2004) Flavonoid quercetin decreases osteoclastic differentiation induced by RANKL via a mechanism involving NF kappa B and AP-1. Journal of Cellular Biochemistry 92, 285-295.

Wehren LE \& Siris ES (2004) Beyond bone mineral density: can existing clinical risk assessment instruments identify women at increased risk of osteoporosis? Journal of Internal Medicine 256, 375-380

Williams FM, Cherkas LF, Spector TD \& MacGregor AJ (2004) A common genetic factor underlies hypertension and other cardiovascular disorders. BMC Cardiovascular Disorders 4, 20 .
Williamson G \& Manach C (2005) Bioavailability and bioefficacy of polyphenols in humans. II. Review of 93 intervention studies. American Journal of Clinical Nutrition 81, 243S-255S.

Woitge HW, Scheidt-Nave C, Kissling C, Leidig-Bruckner G, Meyer K, Grauer A, Scharla SH, Ziegler R \& Seibel MJ (1998) Seasonal variation of biochemical indexes of bone turnover: results of a population-based study. Journal of Clinical Endocrinology and Metabolism 83, 68-75.

Woo JT, Nakagawa H, Notoya M, Yonezawa T, Udagawa N, Lee IS, Ohnishi M, Hagiwara H \& Nagai K (2004) Quercetin suppresses bone resorption by inhibiting the differentiation and activation of osteoclasts. Biological \& Pharmaceutical Bulletin 27, 504-509.

World Health Organization (2003) Prevention and Management of Osteoporosis. WHO Technical Report Series no. 921. Geneva: WHO.

Wu CC, Hsu MC, Hsieh CW, Lin JB, Lai PH \& Wung BS (2005) Upregulation of heme oxygenase-1 by epigallocatechin-3gallate via the phosphatidylinositol 3-kinase/Akt and ERK pathways. Life Sciences (Epublication ahead of print version).

Yamaguchi M \& Jie Z (2001) Effect of polyphenols on calcium content and alkaline phosphatase activity in rat femoral tissues in vitro. Biological and Pharmaceutical Bulletin 24, 1437-1439.

Yamamoto K, Wang J, Yamamoto S \& Tobe H (2000) Suppression of cyclooxygenase-2 gene transcription by humulon of beer hop extract studied with reference to glucocorticoid. FEBS Letters 465, 103-106.

Yang F, Oz HS, Barve S, de Villiers WJ, McClain CJ \& Varilek GW (2001) The green tea polyphenol (-)-epigallocatechin-3gallate blocks nuclear factor-kappa B activation by inhibiting I kappa B kinase activity in the intestinal epithelial cell line IEC-6. Molecular Pharmacology 60, 528-533.

Yun JH, Pang EK, Kim CS, Yoo YJ, Cho KS, Chai JK, Kim CK \& Choi SH (2004) Inhibitory effects of green tea polyphenol (-)-epigallocatechin gallate on the expression of matrix metalloproteinase-9 and on the formation of osteoclasts. Journal of Periodontal Research 39, 300-307.

Zafrilla P, Morillas J, Mulero J, Cayuela JM, Martinez-Cacha A, Pardo F \& Lopez Nicolas JM (2003) Changes during storage in conventional and ecological wine: phenolic content and antioxidant activity. Journal of Agricultural and Food Chemistry 51, 4694-4700.

Zwerina J, Tzima S, Hayer S, Redlich K, Hoffmann O, HanslikSchnabel B, Smolen JS, Kollias G \& Schett G (2005) Heme oxygenase 1 (HO-1) regulates osteoclastogenesis and bone resorption. FASEB Journal 19, 2011-2013. 